\title{
IMPLEMENTASI PENINGKATAN KUALITAS PELAYANAN PUBLIK PEMERINTAH DAERAH KABUPATEN BONE, SULAWESI SELATAN
}

\author{
Oleh \\ Dr. Wiratno, SH.,MH.*) \\ wiratnotrisakti@gmail.com \\ Fakultas Hukum Universitas Trisakti Jakarta
}

\section{Abstrak}

Pelayanan publik adalah kegiatan atau rangkaian kegiatan dalam rangka pemenuhan kebutuhan pelayanan sesuai dengan peraturan perundang-undangan bagi setiap warga negara dan penduduk atas barang, jasa, dan/atau pelayanan administratif yang disediakan oleh penyelenggara pelayanan publik. Penyelenggara pelayanan publik adalah setiap institusi penyelenggara negara, korporasi, lembaga independen yang dibentuk berdasarkan undang-undang untuk kegiatan pelayanan publik, dan badan hukum lain yang dibentuk semata-mata untuk kegiatan pelayanan publik. Dalam menetapkan penyelenggaraan pelayanan publik, Penyelenggara harus memperhatikan asas pelayanan publik, yaitu asas: a) kepentingan umum; b) kepastian hukum; c) kesamaan hak; d) keseimbangan hak dan kewajiban; e) keprofesionalan; f) partisipatif; g) persamaan perlakuan/tidak diskriminatif; $h$ ) keterbukaan; i) akuntabilitas; j) fasilitas dan perlakuan khusus bagi kelompok rentan; k) ketepatan waktu; dan l) kecepatan, kemudahan, dan keterjangkauan. Di samping itu, hal-hal yang harus dilakukan dalam penyelenggaraan pelayanan publik, meliputi: 1) Standar Pelayanan; 2) Maklumat Pelayanan; 3) Sistem Informasi Pelayanan Publik; 4) Pengelolaan Sarana, Prasarana, dan/atau Fasilitas Pelayanan Publik Pengawasan internal; 5) Pelayanan Khusus; 6) Biaya/Tarif Pelayanan Publik; 7) Perilaku Pelaksana dalam Pelayanan; 8) Pengawasan Penyelenggaraan Pelayanan Publik; 9) Pengelolaan Pengaduan; 10) Penilaian Kinerja; dan 11) Peran serta Masyarakat. Penyelenggaraan dan pelaksanaan pelayanan publik yang prima oleh pemerintah dapat merupakan indikator adanya tata-kelola pemerintahan yang baik atau Good governance. Dengan kata lain, tidak ada pemerintahan yang dapat disebut lebih atau semakin baik, apabila tidak adanya bukti bahwa pelayanan publik semakin baik dan semakin berkualitas. Penelitian ini meneliti Implementasi Pelaksanaan Pelayanan Publik di Pemerintah Daerah Kabupaten Bone, Sulawesi Selatan. Hasil penelitian menunjukkan Pemerintah Daerah Kabupaten Bone telah menerapkan prinsipprinsip dan melaksanakan pelayanan publik dengan sangat baik, sebagaimana diamanatkan dalam Undang-Undang Nomor 25 Tahun 2009 tentang Pelayanan Publik.

\section{Kata Kunci : Pelayanan Publik}

\section{A.PENDAHULUAN}

Good governance adalah konsep pengelolaan pemerintahan yang menekankan pada pelibatan unsur pemerintahan, masyarakat dan swasta secara propor- sional sebagai tiga pilar utama. Konsep inilah yang memberi garis dasar bahwa siapapun yang berperan dan peran apapun yang dijalankan dalam penyelenggaraan pemerintahan dituntut untuk lebih berorientasi kepada pelayanan

*) Penulis adalah Dosen Fakultas Hukum

Universitas Trisakti Jakarta 
publik yang semakin baik. Dengan kata lain, tidak ada pemerintahan yang dapat disebut lebih atau semakin baik, jika tidak ada bukti bahwa pelayanan publik semakin baik dan semakin berkualitas. Pada saat ini, penerapan prinsip good governance tidak lagi dipandang sebagai keharusan karena ada desakan, tetapi sudah ditempatkan sebagai suatu kebutuhan organisasi untuk mempertahankan keberadaannya (eksistensi). Tanpa penerapan prinsip-prinsip good governance setiap organisasi dipastikan akan terancam keberadaan dan keberlanjutannya. Itu sebabnya mengapa organisasiorganisasi swasta (komersial) sekarang ini sudah semakin gigih menerapkan good corporate governance. Negara Republik Indonesia yang merupakan negara hukum dan menganut asas kedaulatan rakyat, prinsip good governance mempunyai arti yang sangat penting, yaitu kepentingan rakyat yang berdaulat merupakan tujuan yang harus dicapai dan diselenggarakan oleh negara. Tujuan negara tersebut, secara garis besar dirumuskan dalam UUD 1945 dan secara terperinci dirumuskan di dalam berbagai peraturan perundangan yang merupakan peraturan pelaksanaannya. Untuk mencapai tujuan tersebut ditetapkanlah:

1. Sistem Perencanaan Pembangunan Nasional, diatur dalam Undang-Undang Nomor: 25 Tahun 2004 yang menyatakan, bahwa penjabaran dari tujuan dibentuknya Republik Indonesia seperti dimuat dalam Pembukaan UUD 1945 dituangkan dalam bentuk RPJP (Rencana Pembangunan Jangka Panjang). Skala waktu RPJP adalah 20 tahun, yang kemudian dijabarkan dalam RPJM (Rencana Pembangunan Jangka Menengah), yaitu perencanaan dengan skala waktu 5 tahun yang memuat visi, misi dan program pembangunan dari presiden terpilih dengan berpedoman pada RPJP. Di tingkat daerah, Pemda harus menyusun sendiri RPJP dan RPJM Daerah, dengan merujuk kepada RPJP Nasional.

2. Rencana Pembangunan Jangka Panjang Nasional. Rencana Pembangunan Jangka Panjang Nasional (di-singkat RPJP Nasional), adalah dokumen perencanaan pembangunan nasional untuk periode 20 (dua puluh) tahun. RPJP Nasional untuk tahun 2005 sampai dengan 2025 diatur dalam Undang-Undang Nomor 17 Tahun 2007. Pelaksa-naan RPJP Nasional 20052025 terbagi dalam tahap-tahap perencanaan pembangunan dalam periodisasi perencanaan pembangunan jangka menengah nasional 5 (lima) tahunan.

3. Rencana Pembangunan Jangka Menengah Nasional. Rencana Pembangunan Jangka Menengah Nasional, (disingkat RPJM Nasional), adalah dokumen perencanaan untuk periode 5 (lima) tahun yang terdiri dari :

a. RPJM Nasional I Tahun 2005-2009, b. RPJM Nasional II Tahun 2010-2014, c. RPJM Nasional III Tahun 2015-2019, d. RPJM Nasional IV Tahun 2020-2024. RPJM tersebut kemudian dijabarkan ke dalam Rencana Kerja Pemerintah (RKP) setiap tahunnya.

4. Rencana Kerja Pemerintah. Rencana Kerja Pemerintah (disingkat RKP) adalah rencana pembangunan tahunan nasional, yang memuat prioritas pembangunan nasional, rancangan kerangka ekonomi makro yang mencakup gambaran perekonomian secara menyeluruh termasuk arah kebijakan fiskal, serta program kementerian/ lembaga, lintas kementerian/lembaga kewilayahan dalam bentuk kerangka regulasi dan pendanaan yang bersifat indikatif. RKP merupakan pedoman bagi penyusunan Anggaran Pendapatan dan Belanja Negara (APBN).

5. Rencana Pembangunan Jangka Panjang Daerah. Rencana Pembangunan Jangka Panjang Daerah (disingkat 
RPJP Daerah) adalah dokumen perencanaan pembangunan daerah untuk periode 20 (dua puluh). RPJP Nasional untuk tahun 2005 sampai dengan 2025 diatur dalam Undang-Undang Nomor 17 Tahun 2007. RPJP Daerah yang memuat visi, misi, dan arah Pembangunan Jangka Panjang Daerah disusun mengacu kepada RPJP Nasional.

6. Rencana Pembangunan Jangka Menengah Daerah. Rencana Pembangunan Jangka Menengah Daerah, (disingkat RPJM Daerah) adalah dokumen perencanaan pembangunan daerah untuk perioda 5 (lima) tahunan yang merupakan penjabaran dari visi, misi, dan program kepala daerah dengan berpedoman pada RPJP Daerah serta memerhatikan RPJM Nasional.

Selanjutnya untuk menjamin adanya kepastian hukum agar tugas administrasi negara dijalankan dengan baik dan profesional, maka dikeluarkanlah seperangkat peraturan, yaitu: Undang-Undang Nomor 25 Tahun 2009 tentang Pelayanan Publik, Undang-Undang Nomor 30 Tahun 2014 tentang Administrasi Pemerintahan Negara, Undang-Undang Nomor 14 Tahun 2008 tentang Keterbukaan Informasi Publik, Undang-Undang Nomor 37 Tahun 2008 tentang Ombudsman.

Di samping kebijakan di bidang peraturan, maka untuk dapat mencapai dan menyelenggarakan tujuan-tujuan tersebut diperlukan juga suatu organisasi administrasi negara yang melakukan tugas negara. Tugas administrasi negara adalah untuk melaksanakan dan menyelenggarakan pencapaian tujuan-tujuan negara, sebagaimana dirumuskan dalam UUD dan berbagai peraturan pelaksanaannya.

Berbagai usaha dan inovasi telah dilakukan demi tercapai dan terselenggaranya tujuan negara tersebut, yaitu dengan mencari model yang lebih efektif dalam mewujudkan pemerintahan yang baik. Di lingkungan birokrasi juga telah dilakukan sejumlah inisiatif untuk membentuk birokrasi yang semakin memenuhi tuntutan masyarakat. Konsep dan prinsip pemerintahan yang baik (good governance) telah digunakan sebagai parameter penilaian tingkat kemajuan penyelenggaraan.

Pada organisasi publik (organisasi pemerintah dan satuan-satuannya) peningkatan kualitas pelayanan publik adalah titik penting sebagai ujung akhir dari keseluruhan reformasi administrasi pemerintahan di Indonesia. Hal ini beralasan oleh karena kualitas pelayanan yang diselenggarakan oleh sektor publik sampai saat ini masih sangat memprihatinkan. Begitu banyak pengaduan (keluhan) atau pernyataan ketidakpuasan masyarakat terhadap kualitas pelayanan publik. Karena itu, kinerja pelayanan publik menjadi titik strategis di mana kepercayaan masyarakat secara luas kepada pemerintah dipertaruhkan.

Pelaksanaan dan penyelenggaraan pelayanan publik tersebut, selanjutnya dilakukan melalui kegiatan-kegiatan administrasi negara. Kegiatan administrasi negara ini merupakan bagian yang sangat penting dalam Hukum Administrasi Negara (HAN), karena apabila tidak dilakukan dengan baik, maka kegiatan ini adalah yang paling banyak menimbulkan permasalahan, dan kadang-kadang juga keresahan di kalangan masyarakat. Hal ini akan lebih tampak, karena dalam kehidupan negara modern, campur tangan negara ke dalam kehidupan masyarakat semakin meluas.

Sehubungan dengan pertimbangan tersebut di atas, maka adanya Hukum Administrasi Negara, khususnya yang mengatur tentang penyelenggaraan pelayanan publik merupakan syarat utama dalam memberikan pelayanan publik yang transparan, bermutu dan profesional dan dapat mencegah terjadinya 
maladministrasi serta penyalahgunaan wewenang publik.

Salah satu pemerintah daerah yang melaksanakan pelayanan publik yang baik, transparan, bermutu dan profesional adalah Pemerintah Daerah Kabupaten Bone, Sulawesi Selatan.

Permasalahan yang diajukan dalam penelitian ini adalah bagaimana Implementasi Peningkatan Kualitas Pelayanan Publik Pemerintah Daerah Kabupaten Bone, Sulawesi Selatan, yang berkaitan dengan:

1. Standar Pelayanan;

2. Maklumat Pelayanan;

3. Sistem Informasi Pelayanan Publik;

4. Pengelolaan Sarana, Prasarana, dan/ atau Fasilitas Pelayanan Publik Pengawasan internal;

5. Pelayanan Khusus;

6. Biaya/Tarif Pelayanan Publik;

7. Perilaku Pelaksana dalam Pelayanan;

8. Pengawasan Penyelenggaraan Pelayanan Publik;

9. Pengelolaan Pengaduan;

10. Penilaian Kinerja

Adapun tujuan dari penelitian ini adalah untuk mengetahui tentang Implementasi Peningkatan Kualitas Pelayanan Publik Pemerintah Daerah Kabupaten Bone, Sulawesi Selatan, yang berkaitan dengan:

1. Standar Pelayanan;

2. Maklumat Pelayanan;

3. Sistem Informasi Pelayanan Publik;

4. Pengelolaan Sarana, Prasarana, dan/ atau Fasilitas Pelayanan Publik Pengawasan internal;

5. Pelayanan Khusus;

6. Biaya/Tarif Pelayanan Publik;

7. Perilaku Pelaksana dalam Pelayanan;

8. Pengawasan Penyelenggaraan Pelayanan Publik.

\section{B. PEMBAHASAN}

\section{Tinjauan Umum Negara Hukum Dan Campur Tangan Negara Dalam Kehi- dupan Masyarakat}

Dalam setiap negara selalu terdapat dikotomi (pembagian menjadi dua), yaitu dari segi kepentingan rakyat (warga masyarakat pada umumnya) dan penguasa negara (para pejabat dan petugas negara pada umumnya). Bagi rakyat (para warga masyarakat) masalah pokoknya adalah bagaimana mendapatkan dan mempertahankan hidup yang layak, antara lain mencakup bidang kesejahteraan, kesehatan, pendidikan, dan perumahan serta keamanan.

Bagi penguasa negara (para pejabat dan petugas negara) masalah pokoknya adalah bagaimana penguasa negara dapat menunaikan tugas dan kewajiban dengan baik, artinya efektif (sesuai dengan apa yang menjadi ketentuan undang-undang atau yang diperintahkan oleh pimpinan atasan) dan aman (tidak ada gangguan untuk bekerja jujur, rajin, disiplin dan menurut hukum). Dengan pertimbangan tersebut, maka untuk mencegah konflik dari adanya dikotomi, maka lahirlah asas negara hukum (rechtsstaat) yang pada prinsipnya mengatur antara kepentingan rakyat dan negara.

Pada abad ke-19 dan permulaan abad ke-20, gagasan mengenai perlunya pembatasan kekuasaan negara mendapat perumusan yang yuridis. Ahli hukum Eropa Barat Kontinental, seperti Immanuel Kant (1724-1804) dan Friedrich Julius Stahl mamakai istilah Rechtsstaat, sedangkan ahli Anglo Saxon, seperti A.V. Dicey memakai istilah Rule of Law.

Unsur-unsur Rechtsstaat, menurut konsep Eropa Kontinental adalah:

1. Adanya perlindungan hak-hak manusia; 
2. Pemisahan atau pembagian kekuasaan untuk menjamin hak-hak manusia (trias poltica);

3. Pemerintah berdasarkan peraturanperaturan (wetmatigheid van bestuur);

4. Adanya peradilan administrasi dalam perselisihan.

Dengan maksud atau tujuan yang sama di negara-negara Anglo Saxon lahir asas "the rule of law state", negara berdasarkan kekuasaan hukum. Praktek penerapan ajaran "the rule of law state", misalnya terdapat di Inggris, Malaysia, Singapura dan Australia.

Unsur-unsur Rechtsstaat, menurut konsep Englo Saxon adalah:

1. Supremasi aturan-aturan hukum (supremacy of the law); tidak adanya kekuasaan sewenang-wenang (absence of arbitrary power), dalam arti bahwa seseorang hanya boleh dihukum kalau melanggar hukum;

2. Kedudukan yang sama dalam menghadapi hukum (equality before the law). Dalil ini berlaku baik untuk orang biasa maupun untuk pejabat;

3. Terjaminnya hak-hak manusia oleh undang-undang (di negara lain oleh undangundang dasar) serta keputusan-keputusan pengadilan.

Sesuai dengan perubahan dalam kehidupan bernegara, maka perumusan yuridis mengenai negara hukum klasik dalam abad ke-19 juga ditinjau kembali dan dirumuskan sesuai dengan tuntutan abad ke-20, yang mengarah konsep negara welfare state (negara kesejahteraan).

International Commission of Jurists yang merupakan suatu organisasi ahli hukum internasional dalam konferensinya di Bangkok tahun 1965 sangat memperluas konsep mengenai Rule of Law, dan menekankan apa yang dinamakannya "the dynamic aspects of the Rule of Law in the modern age". Dianggap bahwa di samping hak-hak politik juga hak-hak sosial dan ekonomi harus diakui dan dipelihara. Hal ini berarti campur-tangan pemerintah dalam kerangka welfare state (negara kesejahteraan) harus didasarkan untuk kesejahteraan warga masyarakatnya.

Dalam konsep welfare state syarat untuk terselenggaranya pemerintah yang demokratis di bawah Rule of Law adalah:

1. Perlindungan konstitusionil, dalam arti bahwa konstitusi selain menjamin dari hak-hak individu, harus menentukan pula cara proseduril untuk memperoleh perlindungan atas hakhak yang dijamin.

2. Badan kehakiman yang bebas dan tidak memihak (Independent and impartial tribunals);

3. Pemilihan umum yang bebas;

4. Kebebasan untuk menyatakan pendapat;

5. Kebebasan untuk berserikat/berorganisasi dan beroposisi;

6. Pendidikan kewarganegaraan (civic education).

Dalam setiap negara modern (welfare state) banyak sekali campur tangan penguasa negara kedalam bidang kehidupan masyarakat sehari-hari, antara lain: (a) campur tangan di bidang politik, (b) dalam bidang ekonomi, (c) dalam bidang sosial budaya : kehidupan keluarga, perkawinan, perhimpunan, hiburan, kesenian, olah raga, dan sebagainya (d) dalam bidang agama dan kepercayaan, dan bidang teknologi.

Semua macam campur tangan penguasa negara tersebut diberi bentuk hukum agar supaya segala sesuatunya tidak bersimpang siur dan tidak menimbulkan keragu-raguan pada semua pihak yang bersangkutan, dan bilamana timbul konflik penyelesaian lebih mudah.

Menurut Prayudi, Hukum Administrasi Negara (HAN) merupakan legal matrix daripada administrasi negara, sehingga apapun dan dalam bentuk apapun administrasi negara berbuat, di sana harus ada aturan-aturan HAN (administratieve 
rechtsregels) yang harus membenarkan kegiatan tersebut secara hukum (juridische rechtvaardiging). Hal ini merupakan salah satu konsekuensi daripada asas negara hukum (rehctsstaat).

Bentuk hukum termasuk di atas adalah mutlak perlu, sebab fungsi-fungsi hukum modern adalah untuk:

1. Menata-tertibkan masyarakat,

2. Mengatur lalu-lintas kehidupan bersama masyrakat,

3. Mencegah atau menyelesaikan sengketa (konflik),

4. Menegakkan keamanan dan ketertiban, dimana perlu dengan kekerasan.

5. Mengatur tata cara penegakan keamanan dan ketertiban

6. Mengubah tatanan masyarakat seperlunya bilamana perlu disesuaikan kepada kebutuhan (perubahan) keadaan,

7. Mengatur tata cara pengubahan atau perubahan keadaan.

Fungsi-fungsi hukum tersebut harus dijalankan dengan tidak mengurangi atau menggangu prinsip-prinsip hukum : (1) keadilan (justice, equity), (2) kewajaran (decency, reasonability), (3) effisiensi (4) kepastian hukum (legal security), dan (5) ketenangan hidup (peaceful life).

Pada akhirnya campur tangan penguasa negara tersebut dilakukan oleh para Pejabat/Petugas Administrasi Negara, dan disinilah letak pentingnya Hukum Administrasi Negara.

Pada dasarnya, campur tangan penguasa/negara tersebut telah menimbulkan dua masalah besar pada saat ini, yaitu:

1. Masyarakat semakin lama sangat tergantung dari keputusan-keputusan para pejabat administrasi negara, oleh karena semakin lama banyak urusan yang diikat kepada suatu izin atau persetujuan pemerintah;

2. Bagaimana membuat administrasi negara tersebut berfungsi secara sehat dan selalu memenuhi syarat- syarat sebagai suatu aparatur negara yang bonafide.

Oleh karena itu, agar masalah administrasi negara dapat dilakukan dengan baik, maka dalam rangka penuaian tugas, fungsi dan kewajibannya harus dilakukan berdasarkan syaratsyarat sebagai berikut:

1. Efektivitas, artinya kegiatannya harus mengenai sasaran atau tujuan yang telah ditetapkan atau direncanakan;

2. Legitimitas, artinya kegiatan administrasi negara jangan sampai menimbulkan heboh oleh karena tidak dapat diterima oleh masyarakat setempat atau lingkungan yang bersangkutan;

3. Yuridikitas, artinya syarat yang menyatakan, bahwa perbuatan para pejabat administrasi negara tidak boleh melawan atau melanggar hukum;

4. Legalitas, artinya bahwa tidak satupun perbuatan atau keputusan administrasi negara yang boleh dilakukan tanpa dasar atau suatu ketentuan undang-undang (tertulis); apabila sesuatu dijalankan dengan dalih "keadaan darurat", maka kedaruratan tersebut wajib dibuktikan kemudian; bilamana kemudian tidak terbukti, maka perbuatan tersebut dapat digugat di pengadilan;

5. Moralitas, adalah moral dan ethik umum maupun kedinasan wajib dijunjung tinggi;

6. Effisiensi, berarti kehematan biaya dan produktivitas wajib diusahakan setinggi-tingginya;

7. Teknik dan Teknologi, wajib dipakai untuk mengembangkan atau mempertahankan mutu prestasi yang sebaik-baiknya.

Selanjutnya, dalam rangka untuk mencapai hal-hal tersebut di atas, maka diperlukan daya upaya agar administrasi negara (penguasa) dapat melakukan tugasnya seperti yang diharapkan. 
Ada empat daya upaya yang dapat dilakukan, yaitu:

1. Pengawasan, baik intern maupun ekstern (DPR (D), BPK, KPK, Akuntan Publik), Akuntan Departemen Keuangan;

2. Pembinaan Sistematis, dilakukan melalui pendidikan, latihan, penelitian dan pengembangan $(R \quad \& \quad D)$ dan konsultansi;

3. Pembinaan Personil, dilakukan melalui sistem remunerasi (penghargaan) yang adil dan motovatif, pengembangan moral dan etik kedinasan yang sehat;

4. Pengembangan Hukum Administrasi Negara, yang sesuai dengan kebutuhan realitas, sehingga dapat diterapkan secara effektif.

Di samping hal tersebut di atas, para pejabat negara dalam menjalankan tugasnya juga mempunyai wewenang publik. Penggunaan daripada wewenang publik harus mengikuti aturan-aturan Hukum Administrasi Negara, agar supaya tidak terjadi penyalahgunaan wewenang. Hal ini disebabkan, bahwa wewenang publik tersebut tidak dapat dilawan dengan jalan biasa.

Wewenang pulik tersebut terdiri atas dua kekuasaan yang luar biasa, yaitu:

1. Wewenang prealabel yang merupakan wewenang melaksanakan keputusankeputusan yang diambil tanpa meminta persetujuan terlebih dahulu dari instansi atau seorang perseorangan yang manapun;

2. Wewenang ex-officio, artinya semua keputusan yang diambil karena jabatan (apalagi berdasarkan sumpah jabatan) tidak dapat dilawan oleh siapa pun dan yang berani melawan dikenakan sanksi pidana (misalnya, Pasal 160, 161, 212, 216 KUHP).

Oleh sebab itu, dalam membuat keputusan (badan atau pejabat yang diberi wewenang publik) harus dibuat berdasarkan aturan main yang telah ditetapkan dan dilaksanakan berdasarkan prinsip-prinsip hukum, yaitu adanya: keadilan (justice, equity), kewajaran (decency, reasonability), effisiensi, kepastian hukum (legal security), dan ketenangan hidup (peaceful life).

Menurut Prayudi, agar supaya wewenang publik dapat dilakukan dengan baik dan tidak adanya penyalahgunaan wewenang, maka dalam penggunaan wewenang tersebut (pembuatan keputusan) terikat kepada tiga asas hukum, yaitu:

1. Asas yuridikitas (rechtmatigheid), artinya, keputusan pemerintahan maupun administratif tidak boleh melanggar hukum (onrechtmatigee overheidsdaad);

2. Asas legalitas (wetmatigheid), artinya keputusan harus diambil berdasarkan suatu ketentuan undang-undang;

3. Asas diskresi (discretie, freies ermessen), artinya pejabat penguasa tidak boleh menolak mengambil keputusan dengan alasan "tidak ada peraturannya", dan oleh karena itu diberi kebebasan untuk mengambil keputusan menurut pendapatnya sendiri asalkan tidak melanggar asas yuridikitas dan asas legalitas. Ada dua macam diskresi, yaitu: diskresi bebas, bilamana undang-undang hanya menentukan batas-batasnya, dan diskresi terikat, bilamana undang-undang menetapkan beberapa alternatif untuk dipilih salah satu yang oleh pejabat Administrasi dianggap paling dekat.

Lebih lanjut, suatu kegiatan administrasi negara selalu merupa-kan unsur penting karena tugas administarsi negara masa kini begitu luas, dan hampir semua menyangkut campur tangan pemerintah (penguasa negara) ke dalam kehidupan masyarakat sehari-hari. Dengan demikian, maka warga masyarakat sangat tergantung dari pelaksanaan tugas serta keputusan-keputusan para pejabat administrasi negara. 
Sehubungan dengan hal tersebut, untuk menjamin kepastian hukum dan rasa keadilan agar tugas administrasi negara tersebut dapat berjalan dengan baik, maka dikeluarkanlah UndangUndang Nomor : 30 Tahun 2014 tentang Administrasi Pemerintahan Negara.

Ruang lingkup pengaturan Administrasi Pemerintahan dalam undangundang ini meliputi semua aktivitas:

1. Badan dan/atau Pejabat Pemerintahan yang menyelenggarakan Fungsi Pemerintahan dalam lingkup lembaga eksekutif;

2. Badan dan/atau Pejabat Pemerintahan yang menyelenggarakan Fungsi Pemerintahan dalam lingkup lembaga yudikatif;

3. Badan dan/atau Pejabat Pemerintahan yang menyelenggarakan Fungsi Pemerintahan dalam lingkup lembaga legislatif; dan

4. Badan dan/atau Pejabat Pemerintahan lainnya yang menyelenggarakan Fungsi Pemerintahan yang disebutkan Undang-Undang Dasar Negara Republik Indonesia Tahun 1945 dan/atau undang-undang.

Pengaturan administrasi pemerintahan tersebut mencakup tentang hak dan kewajiban pejabat pemerintahan, kewenangan pemerintahan, diskresi, penyelenggaraan administrasi pemerintahan, prosedur administrasi pemerintahan, keputusan pemerintahan, upaya administratif, pembinaan dan pengembangan administrasi pemerintahan, dan sanksi administratif.

Dalam undang-undang ini dijelaskan, bahwa penyelenggaraan administrasi pemerintahan berdasarkan:

1. asas legalitas;

2. asas pelindungan terhadap hak asasi manusia; dan

3. AUPB.

(Lihat Pasal $4 \quad \& \quad 5$ Undang-Undang Nomor: 30 Tahun 2014 tentang Administrasi Pemerintahan Negara).
Implementasi Peningkatan Kualitas Pelayanan Publik Pemerintah Daerah Kabupaten Bone, Sulawesi Selatan

VISI KABUPATEN BONE 2018-2023 "Masyarakat Bone yang Mandiri, Berdaya Saing, dan Sejahtera"

Mandiri: kemampuan nyata pemerintah daerah dan masyarakatnya dalam mengatur dan mengurus kepentingan daerah/ rumah tangganya sendiri menurut prakarsa dan aspirasi masyarakatnya, termasuk di dalamnya upaya yang sungguh-sungguh secara bertahap mampu mengurangi ketergantungan terhadap pihak-pihak lain namun tetap melakukan kerja sama dengan daerah-daerah lain yang saling menguntungkan.

Berdaya Saing: mengandung makna terwujudnya kemampuan masyarakat Kabupaten Bone untuk memanfaatkan keunggulan inovasi, komparatif dan kompetitif yang berbasis sumber daya lokal dengan tetap memperhatikan kelestarian lingkungan sehingga mampu bersaing secara regional, nasional bahkan internasional.

Sejahtera: mengandung makna semakin meningkatnya kualitas kehidupan masyarakat dalam memenuhi kebutuhan dasar yang berkelanjutan dalam aspek ekonomi, pendidikan, kesehatan, politik, sosial budaya, lingkungan hidup yang dilingkupi dengan suasana kehidupan yang religius, aman dan kondusif serta didukung infrastruktrur dan tata kelola pemerintahan yang baik.

Visi ini menggantikan Visi Kabupaten Bone 2008-2013

"Bone yang Lebih Maju dan Berdaya Saing dalam Tatanan Masyarakat Religius, Berbudaya, Mandiri dan Demokratis"

\section{MISI KABUPATEN BONE}

Dalam rangka mewujudkan visi tersebut, maka ditetapkan misi sebagai berikut: 
a. Meningkatkan tata kelola pemerintahan yang baik, bersih dan bebas Korupsi, Kolusi dan Nepotisme (KKN).

b. Mengembangkan kemandirian ekonomi dan meningkatkan taraf hidup masyarakat.

c. Meningkatkan akses, pemerataan dan kualitas pelayanan kesehatan, pendidikan dan sosial dasar lainnya.

d. Mengotimalkan akselerasi pembangunan daerah berbasis desa dan kawasan perdesaan.

e. Mendorong penciptaan iklim investasi yang kondusif untuk pengembangan usaha dan mengembangkan inovasi daerah dalam peningkatan pelayanan publik.

f. Meningkatkan budaya politik, penegakan hukum, dan seni budaya dalam kemajemukan masyarakat.

Misi ini menggantikan Misi Kabupaten Bone 2008 -2013, yaitu:

a. Mempertajam pelaksanaan otonomi daerah yang didukung aparatur pemerintah daerah yang professional serta peningkatan partisipasi masyarakat.

b. Mendorong investasi di berbagai bidang usaha melalui peningkatan/penyediaan fasilitas jasa pelayanan dan sistem/jaringan kerjasama dan asosiasi bisnis.

c. Mengembangkan sumberdaya daerah, dan pendayagunaan sumberdaya alam (SDA) secara berkelanjutan, terutama komoditas unggulan yang prosfektif.

\section{Pertumbuhan Ekonomi}

Pertumbuhan ekonomi Pemda Kabupaten Bone berdasarkan data tahun 2008, 6, $40 \%$.

\section{Strategi Pencapaian Visi Dan Misi}

1. Optimalisasi pendayagunaan sumberdaya alam yang berkelanjutan dan peningkatan kapasitas sumber daya manusia secara professional, relegius dan berbudaya.

2. Penguatan kelembagaan.

3. Penciptaan iklim dan peluang usaha yang semakin kondusif yang didukung tersedianya saran/prasarana pelayanan publik yang refresentatif.

4. Penguatan kelembagaan dan peningkatan produktifitas pertanian.

\section{Arah Dan Kebijakan Pembangunan Kabupaten Bone 2008 - 2013}

1. Peningkatan Kualitas Hidup

2. Pembangunan Sosial dan Agama

3. Pemerataan Pembangunan dan Penanggulangan Kemiskinan

4. Peningkatan Ketahanan Pangan dan Gizi

5. Pengembangan Usaha Daerah

6. Pengembangan Perdagangan

7. Pembangunan Koperasi

8. Pengembangan Ilmu Pengetahuan dan Teknologi

9. Pengelolaan Kelautan Dan Pesisir

10. Pembangunan Perkotaan Dan Perdesaan

11. Peningkatan Sumberdaya Alam Dan Lingkungan Hidup

12. Penataan Tata Ruang

13. Pembinaan Politik, Informasi, Komunikasi Dan Media Massa

14. Pembinaan Hukum

15. Peningkatan Pembangunan Perumahan Dan Permukiman

16. Pembinaan Keamanan, Ketertiban, Dan Ketentraman Masyarakat

\section{Program Unggulan}

1. Mandiri

a. Program peningkatan pemerataan dan kualitas derajat kesehatan masyarakat melalui penyediaan sarana dan prasarana kesehatan

b. Program peningkatan kualitas dan pemerataan tenaga medis dan paramedis 
c. Penerapan inovasi dibidang kesehatan berbasis kearifan lokal

d. Program peningkatan dan pemerataan sarana dan prasarana pendidikan serta peningkatan kualitas dan pemerataan tenaga pendidik

e. Penerapan inovasi dibidang pendidikan berbasis kearifan lokal

f. Program pembinaan dan pemberdayaan perempuan dan anak serta masyarakat penyandang disabilitas

g. Program pengentasan kemiskinan by name by address.

2. Berdaya Saing

a. Program penerapan E-Government dalam penyelenggaraan pemerintahan Pembangunan dan Pemanfaatan Pusat Layanan Keselamatan Terpadu (Savety Center)

b. Program pewilayahan komoditas unggulan sumber daya alam berbasis desa/kelurahan

c. Program Menjadikan Bone sebagai Pusat Kebudayaan Bugis di Indonesia

d. Program pengembangan infrastruktur wilayah kecamatan luar kota (membangun desa menata kota)

e. Program layanan data terpusat untuk pengembangan potensi dan kemudahan peluang investasi (Potential Region Dashboard)

f. Program peningkatan kapasitas sumber daya manusia dalam pengelolaan sumber daya alam

3. Sejahtera

a. Penguatan jaringan ekonomi desa dengan optimalisasi peran Badan Usaha Milik Desa

b. Pembangunan pusat ekonomi kawasan kecamatan dan peningkatan bantuan modal usaha bagi industri dan UKMK.

c. Program pembangunan berwawasan lingkungan dan berkelanjutan d. Program pengembangan kehidupan beragama dan pemberian insentif Imam Masjid dan Guru Mengaji.

e. Ekstensifikasi dan intensifikasi pemanfaatan lahan pertanian serta pemanfaatan teknologi dalam peningkatan produksi pertanian, perkebunan, peternakan dan perikanan

f. Program pelatihan calon tenaga kerja berbasis desa/kelurahan serta fasilitasi penempatan dan pembinaan tenaga kerja

g. Program bantuan hukum untuk masyarakat miskin.

\section{Program Strategis Daerah Tahun 2009}

1. Sektor Pendidikan dengan Indikator dan Target untuk Mengukur Keberhasilan Sektor Pendidikan Beberapa Program Strategis di Bidang Pendidikan, antara lain:

a. Implementasi Kebijakan Akses Pendidikan

1) Perluasan Akses Pendidikan

a) APK (Angka Partisipasi Kasar) PAUD

b) APM (Angka Partisipasi Murni) $\mathrm{SD} / \mathrm{MI} / \mathrm{SDLB} /$ Pakaet A

c) APK SMP/MTS/Paket B

d) APK SMA/MA?SMK/Paket C

e) Prosentase Buta Aksara > 15 Tahun

2) Pemerataan Akses Pendidikan

a) Disparitas APK PAUD antara Kota/Desa

b) Disparitas APK/SD/MI/SDLB Antara Kota/Desa

c) Disparitas APK SMP/MTS/ Paket B

d) Disparitas APK SMA/MA/ SMK/Paket C

e) Disparitas Prosentase Buta Aksara > 15 Tahun

b. Implementasi Mutu, Relevansi dan Daya Saing Pendidikan

1) Peningkatan Mutu dan Daya Saing Pendidikan 
a) Rata-rata Nilai UN SD/MI

b) Rata-rata Nilai UN SMP/MTS

c) Rata-rata Nilai UN SMA/SMK

d) Guru yang memenuhi kualifikasi S1/DIV

e) Pendidik yang memiliki Sertifikasi Pendidikan

2) Peningkatan Relevansi Pendidikan

a) Rasio jumlah murid SMK: SMA

b) Persentase peserta Pendidikan Live Skill terhadap lulusan

c) SMP/MTS atau SMA/SMK/ MA yang melanjutkan

c. Upaya yang dilakukan Pemerintah Daerah untuk mencapai target yang telah ditentukan, yaitu:

1) PAUD :

a) Membangun Lembaga PAUD yang holistic dan terintegrasi (Taman Paditungka) untuk semua desa yang tidak memiliki lembaga PAUD;

b) Revitalisasi posyandu menjadi Taman PAUD;

c) Penurunan intevensi usia TK (4-6 tahun) menjadi (0-6 tahun)

2) $\mathrm{SD} / \mathrm{MI}$ :

a) Mempertahankan capaian APK yang sekarang ini dengan harapan anak uisa 7-12 tahun telah mendapat layanan Pendidikan dasar;

b) Rehabilitasi Gedung SD/MI (2008 sebanyak 99 sekolah, 2009 sebanyak 135 sekolah dan 2013 semua sekolah sudah rampung);

c) Pemerataan penempatan tenaga kependidikan (minimal 9 orang tenaga kependidikan 1 sekolah)

d) Peningkatan kualitas manajemen sekolah (program MBS).

3) SMP/MTs
Target Pemerintah Pusat pada tahun 2009 semua sekolah yang ada di Indonesia telah tuntas WAJAR dengan indikasi APK SMP/MTs telah mencapai $95 \%$. Karena tuntutan tersebut kebijakan Pemda Kabupaten Bone dalam hal upaya pencapaian APK 2009 sebanyak $95 \%$ anatar lain menggalakan SMP Satap (SMP satu atap SD bagi wilayah terpencil), pembangunan Ruang Kelas Baru bagi SMP yang kekurangan ruang kelas dan pembangunan Unit Sekolah Baru SMP serta pelaksanaan Kejar Paket B.

4) SMA/MA/SMK Untuk mencapai target APK Pemerintah Daerah tahun 2009 sampai tahun 2013, maka strategi yang ditempuh antara lain pembangunan Ruang Kelas Baru bagi SMA yang kekurangan ruang kelas, Pembangunan Unit Sekolah Baru SMA/ SMK, membuka kelas jauh SMA bagi wilayah terpencil dan pelaksanaan Kejar Paket C.

d. Upaya Strategis yang Dilakukan Pemerintah dalam hal Pendidikan Kualitas Tenaga kependidikan di Kabupaten Bone

1) Sertifikasi Guru semua jenjang Pendidikan

2) Musyawarah Guru Mata Pelajaran (MGMP) jenjang SMP dan SMA

3) Kelompok Kerja Guru (KKG) jenjang SD dan PAUD

4) Pelatihan penyusunan KTSP

2. Sektor Kesehatan

a. Prioritas Program Bidang Kesehatan

1) Sektor Gizi

a) Penurunan jumlah balita gizi buruk melalui perbaikan pola asuh, perbaikan gizi keluarga 
dengan memanfaatkan sumber daya local

b) Penurunan jumlah ibu dan wanita usia subur yang kurang gizi

c) Subsidi bagi keluarga miskin melalui Jamkesmas dan askeskin

2) Sektor KIA

a) Menurunkan angka kematian ibu melalui perbaikan pelayanan KIA dan peningkatan cakupan layanan KIA, terutama bagi ibu dan balita di keluarga miskin

b) Penambahan jumlah bidan desa

c) Peningkatan jumlah pemakaian garam beryodium rumah tangga

d) Peningkatan cakupan imunisasi

e) Peningkatan pemakaian alat kontrasepsi pada pasangan usia subur, dengan subsidi pada keluarga miskin serta peningkatan partisipasi suami dalam pemakaian alat kontrasepsi

3) Peningkatan Pelayanan

a) Peningkatan jumlah Polindes

b) Revitalisasi Posyandu melalui replikasi Taman Paditungka

c) Peningkatan akses jamban keluarga

b. Target Penurunan Kematian Bayi dan Balita

c. Target Penurunan Jumlah Kematian Ibu

d. Frekuensi Pemeriksaan Kehamilan

e. Target Peningkatan Cakupan Persalinan Tenaga Kesehatan

f. Target Peningkatan Cakupan K4

g. Target Peningkatan Penggunaan Alat Kontrasepsi pada WUS yang Menilah

h. Peningkatan Penggunaan Garam Beryodium i. Target Cakupan Imunisasi Campak

j. Target Peningkatan Cakupan Vitamin A

k. Target Peningkatan Presentase Remaja yang Memiliki Pengetahuan Komprehensif mengenai HIV/AIDS

3. Bidang Tenaga Kerja

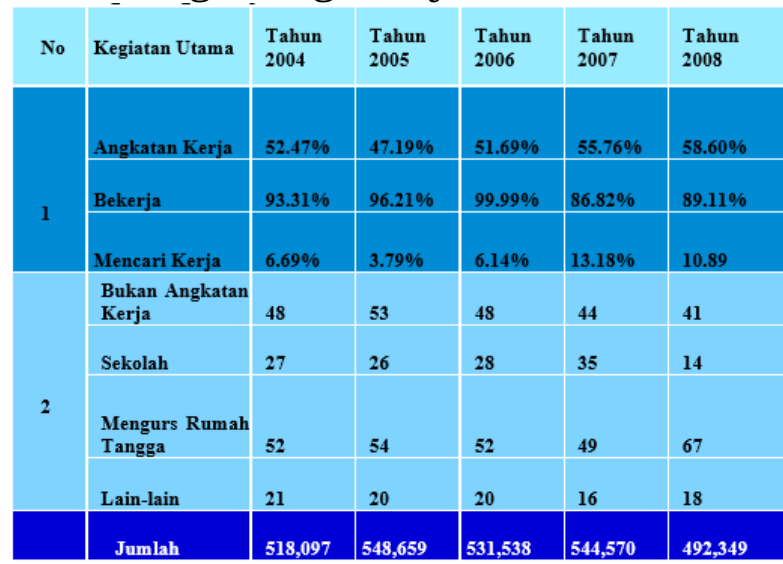

4. Bidang Kependudukan

Skala prioritas bidang kependudukan mencakup:

a. Target penurunan penduduk miskin

b. Meningkatkan Angka Harapan Hidup (AHH)

c. Cakupan Peserta KB Aktif

d. Akses terhadap Sanitasi Dasar

e. Cakupan Air Bersih

5. Bidang Transportasi Skala Prioritas bidang transportasi mencakup:

a. Inventaritasi panjang jalan Kabupaten menurut Jenisnya

b. Inventarisasi panjang jalan menurut kondisinya

c. Rehabilitasi pembangunan prasarana jalan dan jembatan tahun $2008 \& 2009$

d. Sarana penanggulangan lahan kritis tahun 2008-20013 
6. Bidang Ekonomi

a. Perkembangan Investasi Dana Pemerintah Kabupaten Bone Tahun $2003-2008$

\begin{tabular}{|c|c|c|c|}
\hline \multicolumn{4}{|c|}{$\begin{array}{l}\text { PERKEMBANGAN INVESTASI DANA PEMIERINTAH } \\
\text { KABUPATEN BONE TAHUN } 2003-2008\end{array}$} \\
\hline \multirow{2}{*}{ Tahun } & \multicolumn{3}{|c|}{ SUMBER DANA } \\
\hline & APBN/BLN & APBD PROVINSI & APBD KABUPATEN \\
\hline 2004 & $22,112,694,410$ & $2,211,175,874$ & $363,734,951,670$ \\
\hline 2005 & $41,505,361,257$ & $3,149,432,615$ & $382,075,701,010$ \\
\hline 2006 & $102,120,250,000$ & $13,047,256,500$ & $404,406,415,615$ \\
\hline 2007 & $58,804,230,000$ & $23,807,830,496$ & $585,031,868,577$ \\
\hline 2008 & $40,278,093,000$ & $16,702,913,809$ & $775,237,474,497$ \\
\hline $\begin{array}{l}\text { Laju } \\
\text { Pert. }(\theta)\end{array}$ & & & \\
\hline
\end{tabular}

b. Perkembangan dan Pertumbuhan Ekonomi Kabupaten Bone Tahun 2003-2008

\begin{tabular}{|c|c|c|c|c|}
\hline Tahun & $\begin{array}{l}\text { PDRB } a d h \\
\text { Berlaku } \\
\text { (juta Rp) }\end{array}$ & $\begin{array}{l}\text { Perkembangan } \\
\text { (persen) }\end{array}$ & $\begin{array}{l}\text { PDRB adh } \\
\text { Konstan } \\
\text { (juta Rp) }\end{array}$ & $\begin{array}{l}\text { Pertumbuhan } \\
\text { (persen) }\end{array}$ \\
\hline (1) & (2) & (3) & (4) & (5) \\
\hline $\begin{array}{l}2003 \\
2004 \\
2005 \\
2006 \\
2007 \\
2008^{*}\end{array}$ & $\begin{array}{l}2.755 .785,97 \\
2.978 .646,53 \\
3.327 .715,77 \\
3.860 .830,96 \\
4.423 .743,58 \\
\mathbf{5 , 0 8 1 , 5 5 4 . 2 5}\end{array}$ & \begin{tabular}{l|l|}
10,60 \\
8,08 \\
11,72 \\
16,02 \\
14,58 \\
14.87
\end{tabular} & $\begin{array}{l}2.164 .344,20 \\
2.209 .958,50 \\
2.305 .158,94 \\
2.442 .413,22 \\
2.590 .298,03 \\
2,756,623.66\end{array}$ & $\begin{array}{l}4,56 \\
2,11 \\
4,31 \\
5,95 \\
6,05 \\
6,40\end{array}$ \\
\hline $\begin{array}{l}\text { Rata- } \\
\text { rata }\end{array}$ & $\mathbf{x x x x}$ & 12.64 & $x x x x$ & 4.89 \\
\hline
\end{tabular}

c. Proyeksi Perkembangan dan Pertumbuhan Ekonomi Kabupaten Bone Tahun 2009 -2013

\begin{tabular}{|l|l|l|l|l|}
\hline Tahun & $\begin{array}{l}\text { PDRB adh } \\
\text { Berlaku } \\
\text { (juta Rp) }\end{array}$ & $\begin{array}{l}\text { Perkembangan } \\
\text { (persen) }\end{array}$ & $\begin{array}{l}\text { PDRB adh } \\
\text { Konstan } \\
\text { (juta Rp) }\end{array}$ & $\begin{array}{l}\text { Pertumbuhan } \\
\text { (persen) }\end{array}$ \\
\hline (1) & $(2)$ & $(3)$ & $(4)$ & $(5)$ \\
\hline & & & & \\
2009 & $5,850,393.16$ & 15.13 & $2,942,695.76$ & 6.67 \\
2010 & $6,768,319.85$ & 15.69 & $3,146,624.57$ & 6.93 \\
2011 & $7,853,958.35$ & 16.34 & $3,371, .293 .56$ & 7.14 \\
2013 & $9,142,792.92$ & 16.41 & $3,620,432.15$ & 7.39 \\
& $10,653,182.31$ & 16.52 & $3,904,998.12$ & 7.86 \\
\hline
\end{tabular}

d. Nilai Investasi Industri Kabupaten Bone Tahun $2003-2008$

\begin{tabular}{|l|l|l|l|}
\hline \multicolumn{3}{|c|}{ NILAI INVESTASI INDUSTRI KABUPATEN BONE } \\
TAHUN 2003 - 2008 \\
\hline \multirow{3}{*}{ Nilai Investasi (Juta) } \\
\cline { 2 - 4 } Tahun & Industri Menengah & Industri Besar \\
& Industri Kecil & $6,327,035$ & $26,004,835$ \\
2003 & $18,185,523$ & $11,522,465$ & $27,839,835$ \\
2004 & $23,675,369$ & $14,873,468$ & $27,839,835$ \\
2005 & $31,896,753$ & $16,552,008$ & $28,185,835$ \\
2006 & $35,753,839$ & $18,128,008$ & $28,805,835$ \\
2007 & $52,544,326$ & $23,584,538,41$ & $29,551,906$ \\
2008 & $68,507,292,24$ & 30.10 & 2.59 \\
\hline Laju & 30.38 & & \\
Pert.(\%) & &
\end{tabular}

e. Proyeksi Nilai Investasi Industri Kabupaten Bone Tahun 2009 2013

\begin{tabular}{|l|l|l|l|}
\hline \multirow{3}{*}{ Tahun } & \multicolumn{2}{|c|}{ Nilai Investasi (Juta) } \\
\cline { 2 - 4 } & Industri Kecil & Industri Menengah & Industri Besar \\
\hline 2009 & $77,132,360$ & $25,735,448,31$ & $26,004,835$ \\
2010 & $86,843,324$ & $28,859,283,42$ & $29,679,114$ \\
2011 & $104,229,357$ & $33,202,605,57$ & $29,765,183$ \\
2012 & $128,577,339$ & $37,416,553,57$ & $29,869,362$ \\
2013 & $160,881,678$ & $39,059,545,19$ & $29,973,362$ \\
& & & \\
\hline
\end{tabular}

\section{f. Koperasi}

Banyaknya KUD dan Non KUD di Kabupaten Bone Tahun 2003 - 2008

\begin{tabular}{|l|c|l|l|l|l|}
\hline TAHUN & KUD & Non KUD & JUMLAH & Yg aktif & Yg tdk Aktif \\
& & & & & \\
\hline (1) & $\mathbf{( 2 )}$ & $\mathbf{( 3 )}$ & $\mathbf{( 4 )}$ & $\mathbf{( 6 )}$ & $\mathbf{( 5 )}$ \\
& & & 782 & - & \\
\hline 2003 & 40 & $\mathbf{7 4 2}$ & $\mathbf{7 9 8}$ & - & - \\
2004 & $\mathbf{4 0}$ & $\mathbf{7 5 8}$ & $\mathbf{8 0 6}$ & - & - \\
2005 & $\mathbf{4 0}$ & $\mathbf{7 6 6}$ & $\mathbf{8 7 5}$ & - & - \\
$\mathbf{2 0 0 6}$ & $\mathbf{4 0}$ & $\mathbf{8 3 5}$ & $\mathbf{8 7 7}$ & $\mathbf{7 4 0}$ & $\mathbf{1 3 7}$ \\
$\mathbf{2 0 0 7}$ & $\mathbf{4 0}$ & $\mathbf{8 3 7}$ & $\mathbf{8 8 3}$ & $\mathbf{7 4 6}$ & $\mathbf{1 3 7}$ \\
$\mathbf{2 0 0 8}$ & $\mathbf{4 0}$ & $\mathbf{8 4 3}$ & $\mathbf{8 9 0}$ & $\mathbf{7 5 2}$ & $\mathbf{1 3 8}$ \\
$\mathbf{2 0 0 9}$ & $\mathbf{4 0}$ & $\mathbf{8 5 0}$ & & & \\
\hline
\end{tabular}

g. Koperasi

Proyeksi Banyaknya KUD dan Non KUD di Kabupaten Bone Tahun

\begin{tabular}{|l|l|l|l|l|l|}
\hline TAHUN & KUD & Non KUD & JUMLAH & Yg aktif & Yg tdk Aktif \\
\hline$(1)$ & $(2)$ & $(3)$ & $(4)$ & $(6)$ & $(5)$ \\
\hline 2009 & 40 & 843 & 883 & 750 & 133 \\
2010 & 40 & 860 & 900 & 778 & 122 \\
2011 & 40 & 877 & 917 & 810 & 107 \\
2012 & 41 & 894 & 935 & 835 & 100 \\
2013 & 41 & 900 & 941 & 850 & 91 \\
& & & & \\
\hline
\end{tabular}
$2009-2013$ 
h. Produksi Komoditas Unggulan Sektor Kelautan dan Perikanan Kabupaten Bone Tahun 2003 2008 (Ton)

\begin{tabular}{|c|c|c|c|c|c|c|c|c|}
\hline No & URAIA & 2003 & 2004 & 2005 & 2006 & 2007 & 2008 & $\begin{array}{l}\text { \& DER- } \\
\text { THAM }\end{array}$ \\
\hline 1. & $\begin{array}{l}\text { Udang } \\
\text { Windu }\end{array}$ & $1,401$. & 1,205 . & 1,059 . & 858.00 & 820.00 & 824.10 & $(12.38)))$ \\
\hline 2. & Kepiting & $1,921$. & 1,717 & 1,526 . & $1,510.0$ & $1,310.00$ & $1,376.50$ & $(9.02)$ \\
\hline 3. & Tuna & 5,806 . & 5,817 . & $5,820$. & $5,830.0$ & $27,233.6$ & $29,956.96$ & 0.13 \\
\hline 4. & Cakalan & 9,007 . & $9,012$. & 9,019 . & $9,025.0$ & $2,311.30$ & $2,426.87$ & (18.55) \\
\hline 5. & $\begin{array}{l}\text { Rumput } \\
\text { Laut }\end{array}$ & 5,800 . & $5,932$. & 6,108 . & 10,640 . & $26,790.0$ & $30,808.50$ & 57.81 \\
\hline 6. & Layang & 2,485 . & 2,517 & 2,617 & $2,690.0$ & $1,544.90$ & $1,622.15$ & $\begin{array}{l}(8.63) \\
\end{array}$ \\
\hline 7. & $\begin{array}{l}\text { Ikan } \\
\text { Mas }\end{array}$ & 194.10 & 176.00 & 127.70 & 59.0 & 58.70 & 64.57 & $(22.77)$ \\
\hline
\end{tabular}

i. Sasaran Produksi Komoditas Unggulan Sektor Kelautan dan Perikanan Kabupaten Bone Tahun 2009 -2012 (Ton)

\begin{tabular}{|l|l|l|l|l|l|l|}
\hline & URAIAN & 2009 & 2010 & 2011 & 2012 & ₹ PXR- TEM \\
\hline 1. & Udang Windu & 828.22 & 832.36 & 836.52 & 840.71 & 0.50 \\
\hline 2. & Kepiting Bakau & $1,444.28$ & $1,516.49$ & $1,592.31$ & $1,671.93$ & 5.00 \\
\hline 3. & Tuna & $32,952.66$ & $36,247.92$ & $39,872.71$ & $43,859.99$ & 10.00 \\
\hline 4. & Cakalang & $2,348.21$ & 2.675 .62 & $2,809.40$ & $2,949.87$ & 5.00 \\
\hline 5. & Rumput Laut & $35,429.78$ & $40,744.24$ & $46,855.88$ & $53,884.26$ & 15.00 \\
\hline 6. & Layang & $1,703.25$ & $1,788.41$ & $1,877.84$ & $1,971.73$ & 5.00 \\
\hline 7. & Ilan Mas & 71.03 & 78.13 & 85.94 & 94.54 & 10.00 \\
\hline
\end{tabular}

Sumber Data : Dinas Kelautan dan Perikanan Kab. Bone 
7. Bidang Pendapatan Daerah Tahun 2008-2013 Proyeksi Pendapatan Daerah Kabupaten Bone Tahun 20082013 (Milyar Rupiah)

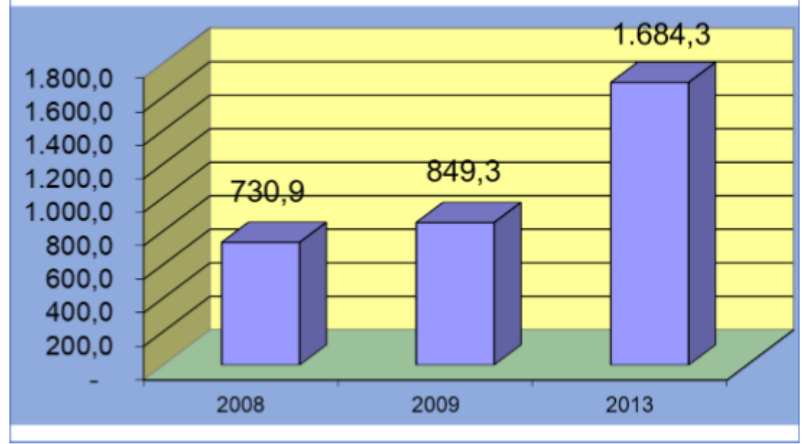

\section{Pelayanan Publik}

Pemerintah Kabupaten Bone dalam melakukan peningkatan kualitas pelayanan publik dilakukan melalui layanan, antara lain:

1. Kependudukan \& Catatan Sipil

2. Perizinan

3. Pengaduan

4. Daftar Informasi Publik

5. Laporan Layanan

6. Indek Kepuasan Masyarakat

\section{Hasil Penilaian Pelayanan Publik Yang Dilakukan Pemerintah Daerah Kabupaten Bone}

Penilaian dilakukan berdasarkan kriteria yang telah ditetapkan oleh Menpan melalui Pedoman Penilaian Kinerja Unit Pelayanan Publik Nomor : PER/25/ M.PAN/05/2006 jo Pelengkap Petunjuk Teknis Penilaian Form A, pada Peraturan Menpan, Nomor : PER/25/M.PAN/05/ 2006, tentang Pedoman Penilaian Kinerja Unit Pelayanan Publik.

Berdasarkan kriteria tersebut dilakukan penilaian oleh Tim Penilai pada tanggal 29 November 2011 - 2 Desember 2011, berdasarkan Surat Tugas B/2768/ D.VI-PAN.RB/11/2011, tanggal 15 November 2011.
Tim penilai diterima langsung oleh Wakil Bupati Bone, mewakili Bupati Bone yang sedang melaksanakan ibadah Umroh. Kegiatan paparan penyelenggaraan pelayanan publik pada Pemerintah Kabupaten Bone dipimpin langsung oleh Wakil Bupati Bone, yang didampingi oleh kepala Bappeda Kabupaten Bone, dan Kepala Bagian Organisasi Setda Kabupaten Bone. Pada kesempatan tersebut, hadir seluruh kepala dinas, badan, kecamatan dan kelurahan serta unsur tokoh masyarakat setempat.

Tim Penilai juga melakukan cross check mengenai berbagai kebijakan yang telah disampaikan oleh Wakil Bupati Bone, dengan melakukan kunjungan lapangan ke SD Negeri Kabupaten Bone, PDAM Kabupaten Bone, Kantor Pelayanan Perizinan Satu Atap, dan Puskesmas.

Hasil penilaian terhadap implementtasi pelayanan publik yang dilakukan oleh Pemerintah Daerah Kabupaten Bone seperti tersebut di bawah ini:

\section{FORM : A (FORMULIR PENILAIAN} KINERJA UNIT PELAYANAN)

\begin{tabular}{|c|c|c|c|c|c|}
\hline No. & $\begin{array}{c}\text { Komponen Penilaian } \\
\text { dan Bobot }\end{array}$ & Indikator & $\begin{array}{c}\text { No } \\
\text { Kode }\end{array}$ & Perkiraan Kondisi & Nilai \\
\hline \multirow[t]{17}{*}{1.} & \multirow{17}{*}{$\begin{array}{l}\text { Visi dan atau misi } \\
\text { serta motto } \\
\text { pelayanan } \\
\text { (Bobot } 10 \%)\end{array}$} & \multirow{6}{*}{$\begin{array}{l}\text { 1) Apakah terdapat visi dan } \\
\text { atau misi yang mampu } \\
\text { memotivasi pegawai untuk } \\
\text { memberikan pelayanan } \\
\text { terbaik? }\end{array}$} & 1 & Tidak ada visi/misi & 0 \\
\hline & & & 2 & Ada, namun sulit untuk dimengerti & 40 \\
\hline & & & 3 & $\begin{array}{l}\text { Ada, namun tidak relevan dengan } \\
\text { pelayanan }\end{array}$ & 50 \\
\hline & & & 4 & Ada, namun tidak memotivasi & 60 \\
\hline & & & 5 & Ada, cukup memotivasi & 80 \\
\hline & & & 6 & Ada, bersifat menantang dan memotivasi & 100 \\
\hline & & \multirow{6}{*}{$\begin{array}{l}\text { 2) Apakah terdapat motto } \\
\text { pelayanan yang mampu } \\
\text { memotivasi pegawai untuk } \\
\text { memberikan pelayanan } \\
\text { terbaik? }\end{array}$} & 7 & Tidak ada motto pelayanan & 0 \\
\hline & & & 8 & Ada, namun sulit untuk dimengerti & 40 \\
\hline & & & 9 & $\begin{array}{l}\text { Ada, namun tidak relevan dengan } \\
\text { pelayanan }\end{array}$ & 50 \\
\hline & & & 10 & Ada, namun tidak memotivasi & 60 \\
\hline & & & 11 & Ada, cukup memotivasi & 80 \\
\hline & & & 12 & Ada, bersifat menantang dan memotivasi & 100 \\
\hline & & \multirow{5}{*}{$\begin{array}{l}\text { 3) Apakah motto pelayanan } \\
\text { diumumkan secara terbuka } \\
\text { kepada masyarakat? }\end{array}$} & 13 & $\begin{array}{l}\text { Tidak diumumkan, hanya diketahui oleh } \\
\text { pegawai. }\end{array}$ & 30 \\
\hline & & & 14 & $\begin{array}{l}\text { Tidak diumumkan, namun hanya } \\
\text { diletakan di dinding dalam ruang pegawai }\end{array}$ & 40 \\
\hline & & & 15 & $\begin{array}{l}\text { Tidak diumumkan, namun hanya } \\
\text { diletakkan di dinding dalam ruang } \\
\text { pegawai }\end{array}$ & 50 \\
\hline & & & 16 & $\begin{array}{l}\text { Diumumkan, namun tidak secara jelas } \\
\text { nampak }\end{array}$ & 60 \\
\hline & & & 17 & Diumumkan, cukup jelas dilihat & 80 \\
\hline
\end{tabular}




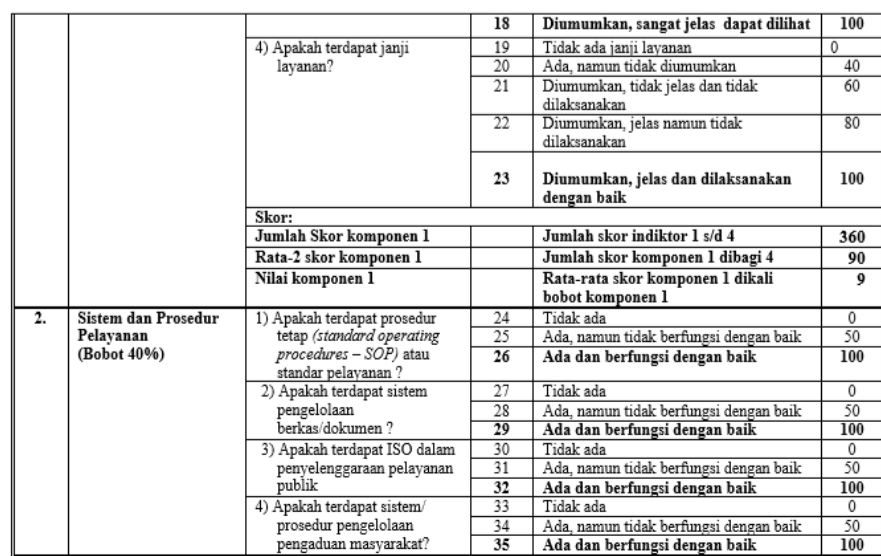

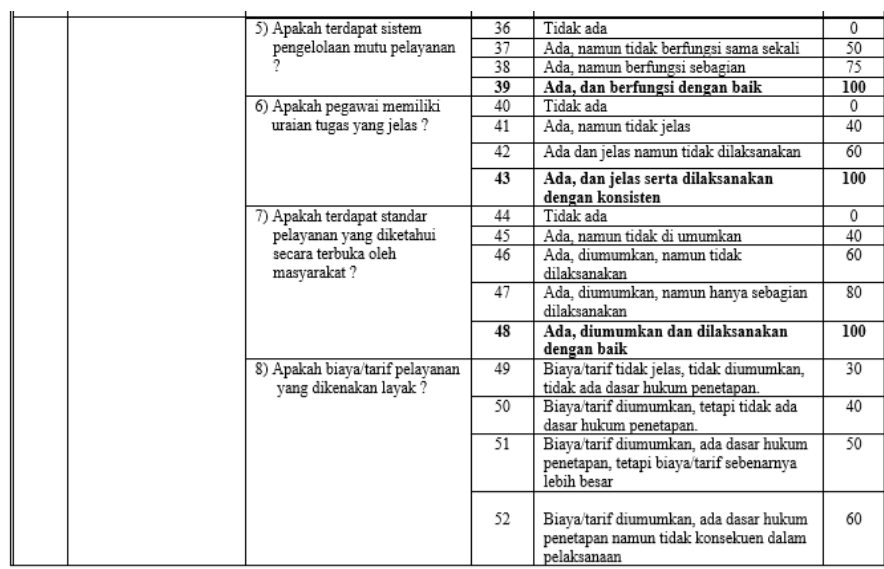

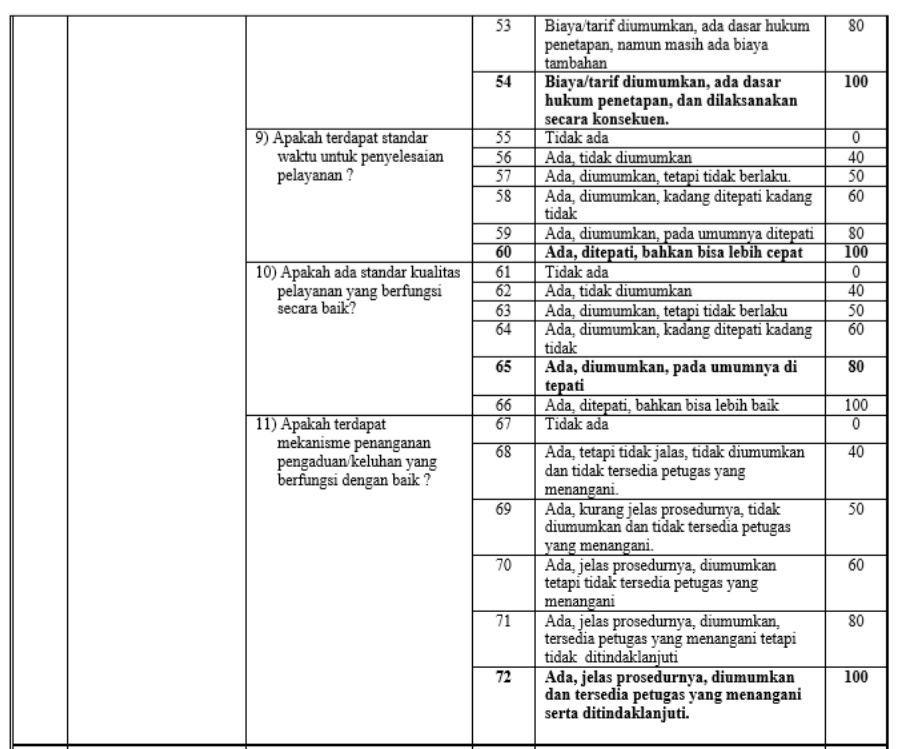

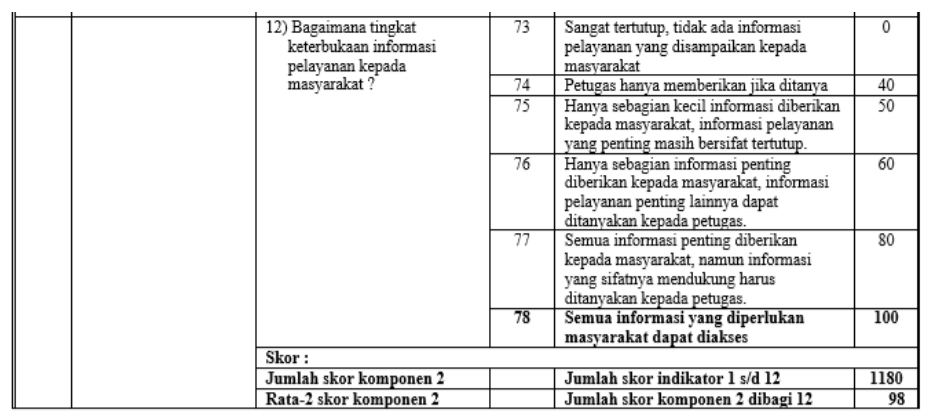

\begin{tabular}{|c|c|c|c|c|c|}
\hline & & Nilai komponen 2 & & $\begin{array}{l}\text { Rata-rata skor komponen } 2 \text { dikali } \\
\text { bobot komponen } 2\end{array}$ & 39 \\
\hline \multirow[t]{39}{*}{3.} & \multirow{23}{*}{$\begin{array}{l}\text { Sumber Daya Manusia } \\
\text { (SDM) Pelayanan } \\
\text { (Bobot } 30 \% \text { ) }\end{array}$} & \multirow{6}{*}{$\begin{array}{l}\text { 1) Apakah terdapat pedoman } \\
\text { intermal tentang sikap dan } \\
\text { perilaku, etika pegawai } \\
\text { dalam pemberian pelayanan } \\
?\end{array}$} & 79 & Tidak ada & 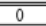 \\
\hline & & & 80 & $\begin{array}{l}\text { Ada, namun tidak berfungsi/ tidak } \\
\text { diterapkan }\end{array}$ & 40 \\
\hline & & & 81 & $\begin{array}{l}\text { Ada, namun sebagian besar tidak } \\
\text { berfungsi t tidak diterapkan }\end{array}$ & 50 \\
\hline & & & 82 & $\begin{array}{l}\text { Ada, hanya sebagian kecil yang } \\
\text { berfunggi/ diterapkan }\end{array}$ & 60 \\
\hline & & & 83 & Ada, sebagian besar berfungsi/ diterapkan & 80 \\
\hline & & & 84 & $\begin{array}{l}\text { Ada, berfungsi/ diterapkan dengan } \\
\text { baik }\end{array}$ & 100 \\
\hline & & \multirow{5}{*}{$\begin{array}{l}\text { 2) Bagaimana sikap dan } \\
\text { perilaku pegawai dalam } \\
\text { memberikan pelayanan } \\
\text { kepada masyarakat ? }\end{array}$} & 85 & Sangat buruk & 0 \\
\hline & & & 86 & Buruk & 40 \\
\hline & & & $\begin{array}{l}87 \\
89\end{array}$ & $\frac{\text { Kurang baik }}{\text { Cukur baik }}$ & $\frac{50}{60}$ \\
\hline & & & 90 & Baik & 80 \\
\hline & & & 91 & Sangat baik & 100 \\
\hline & & \multirow{6}{*}{$\begin{array}{l}\text { 3) Bagaimana kedisiplinan } \\
\text { pegawai dalam memberikan } \\
\text { pelayanan kepada masyarakat? }\end{array}$} & 92 & Sangat tidak disiplin & 0 \\
\hline & & & 93 & Tidak disiplin & 40 \\
\hline & & & 94 & Kurang disiplin & 50 \\
\hline & & & 95 & Cukup disiplin & 60 \\
\hline & & & 96 & Disiplin & 80 \\
\hline & & & 97 & Sangat disiplin & 100 \\
\hline & & \multirow{6}{*}{$\begin{array}{l}\text { 4) Bagaimana tingkat kepekaan/ } \\
\text { respon pegawai dalam } \\
\text { memberikan pelayanan } \\
\text { kepada masyarakat ? }\end{array}$} & 98 & Sangat tidak peka/responsive & 0 \\
\hline & & & 99 & Tidak peka/responsive & 40 \\
\hline & & & 100 & Kurang peka responsive & 50 \\
\hline & & & 101 & Cukup peka responsive & 60 \\
\hline & & & 102 & Peka/responsif & 80 \\
\hline & & & 103 & Sangat peka/ responsif & 100 \\
\hline & & \multirow{6}{*}{$\begin{array}{l}\text { 5) Bagaimana tingkat } \\
\text { ketrampilan pegawai dalam } \\
\text { memberikan pelayanan } \\
\text { kepada masyarakat? }\end{array}$} & 104 & Sangat tidak terampil (sangat lamban, malas) & 0 \\
\hline & & & 105 & Tidak terampil & 40 \\
\hline & & & 106 & Kurang terampil & 50 \\
\hline & & & 107 & Cukup terampil & 60 \\
\hline & & & 108 & Terampil & 80 \\
\hline & & & 109 & Sangat terampil(sangat cepat dan teliti) & 100 \\
\hline & & \multirow{6}{*}{$\begin{array}{l}\text { 6) Apakah terdapat kebijakan } \\
\text { pengembangan pegawai } \\
\text { dalam rangka peningkatan } \\
\text { keterampilan } \\
\text { profesionalisme pegawai } \\
\text { dengan tujuan meningkatkan } \\
\text { kualitas pelayanan kepada } \\
\text { masyarakat? }\end{array}$} & 110 & Tidak ada sama sekali & 0 \\
\hline & & & 111 & $\begin{array}{l}\text { Ada, namun sangat jarang dilakukann dan tidak } \\
\text { relevan dengan upaya peningkatan kualitas } \\
\text { pelaynan }\end{array}$ & 40 \\
\hline & & & 112 & $\begin{array}{l}\text { Ada, sangat jarang dilahukan, hanya untulk } \\
\text { ketrampilan tertentu yang dibutuhkan dalam } \\
\text { rangka peningkata kualitas pelayanan }\end{array}$ & 50 \\
\hline & & & 113 & $\begin{array}{l}\text { Ada, cukup sering, hanya sebagian yang } \\
\text { relevan untuk ketermmilan tertentu yang } \\
\text { dibutuhkan dalam rangka peningkatam } \\
\text { kualitatas pelay anan }\end{array}$ & 60 \\
\hline & & & 114 & $\begin{array}{l}\text { Ada, sering, tetapi tidak selalu kontinyu, dan } \\
\text { sesuai relevan dengan keterampilan tertentu } \\
\text { yang dibuttuhkan dalam rangka peningkatan } \\
\text { kualitas pelayanan }\end{array}$ & 80 \\
\hline & & & 115 & $\begin{array}{l}\text { Secara kontinyu diadakan, sesuai dengan } \\
\text { kebuttuhan }\end{array}$ & 100 \\
\hline & & \multicolumn{4}{|l|}{ Skor: } \\
\hline & & Jumlah skor komponen 3 & & Jumlah skor indikator $1 \mathrm{~s} / \mathrm{d} 6$ & 540 \\
\hline & & Rata-2 skor komponen 3 & & Jumlah skor komponen 3 dibagi 6 & 90 \\
\hline & & Nilai komponen 3 & & $\begin{array}{l}\text { Rata-rata skor komponen } 3 \text { dikali bobot } \\
\text { komponen } 3\end{array}$ & 27 \\
\hline
\end{tabular}




\begin{tabular}{|c|c|c|c|c|c|}
\hline 4. & Sarana dan Prasarana & & 116 & Sarana tidak dipergunakan sama sekali & 0 \\
\hline & \multirow{17}{*}{ (Bobot 20\%) } & \multirow{3}{*}{$\begin{array}{l}\text { 1) Apakah sarana yang di } \\
\text { gunakanu untuk prosess } \\
\text { pelyanan telah digunakan } \\
\text { secara optimal ? }\end{array}$} & 117 & Hanya sebagain kecil sarana yang digumakan & 40 \\
\hline & & & 118 & $\begin{array}{l}\text { Sebagian besar sarana dipergeguakan secara } \\
\text { oftimal }\end{array}$ & \\
\hline & & & 119 & Semua arana dipergunakan secara optimal & 100 \\
\hline & & \multirow{5}{*}{$\begin{array}{l}\text { 2) Apakah sarana pelayanan } \\
\text { yang tersedia memberikan } \\
\text { kenyamanan kepadaa } \\
\text { masyarakat penguma ? } \\
\text { (Perhatikan: kebersihan, } \\
\text { kesederhanaan, kelayakan } \\
\text { dan kemanfaatan) }\end{array}$} & 120 & 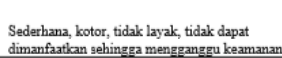 & 0 \\
\hline & & & 121 & 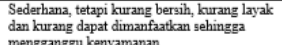 & 40 \\
\hline & & & 122 & 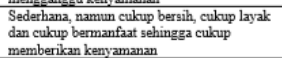 & 60 \\
\hline & & & 123 & 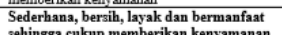 & 80 \\
\hline & & & 124 & 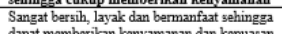 & 100 \\
\hline & & \multirow{6}{*}{$\begin{array}{l}\text { 3) Apakah tersedia sarana } \\
\text { pengaduan keluhan yang } \\
\text { berfungsi secara efektifif? }\end{array}$} & $\frac{125}{126}$ & Tidake dada & 30 \\
\hline & & & & 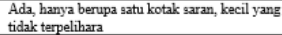 & \\
\hline & & & 127 & 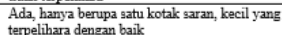 & 50 \\
\hline & & & 128 & 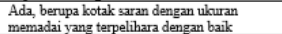 & 60 \\
\hline & & & 129 & 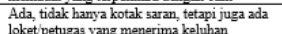 & 80 \\
\hline & & & 130 & 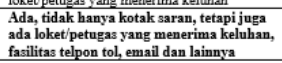 & 100 \\
\hline & & \multirow{3}{*}{\begin{tabular}{|l|} 
Skor: \\
Jumlah Skor komponen 4 \\
Rata-2 2skor komponen 4 \\
Nilai komponen 4
\end{tabular}} & & & \\
\hline & & & & Jumlah skor komponen 4 dibagi 3 & 93 \\
\hline & & & & $\begin{array}{l}\text { Rata-rata skor komponen } 4 \text { dikali } \\
\text { bobot komponen } 4\end{array}$ & \\
\hline
\end{tabular}

Jumlah Komponen Penilaian dan Bobot Penilaian pada Form A:

1. Visi dan atau misi serta motto pelayanan, bobot penilaian $10 \%$ $=9$

2. Sistem dan Prosedur Pelayanan, bobot penilaian $40 \% \quad=39$

3. Sumber Daya Manusia (SDM) Pelayanan, bobot penilaian $30 \% \quad=27$

4. Sarana dan Prasarana,

bobot penilaian $20 \% \quad=18$

Jumlah

$=93$

Dengan memperoleh jumlah penilaian dan bobot penilaian pada Form A 93, maka Pemerintah Daerah Kabupaten Bone telah melakukan standar mutu pelayanan publik yang sangat baik.

Selain melakukan penilaian kinerja pada unit pelayanan sebagaimana dilakukan dengan Form A, Tim Penilai juga melakukan survei bagi pengguna pelayanan publik. Sehubungan dengan hal tersebut, maka ada 10 orang responden, yaitu masyarakat pengguna pelayanan publik telah diminta oleh Tim Penilai untuk memberikan pendapatnya dengan mengisi Form B yang telah disiapkan terhadap pelayanan publik Pemerintah Daerah Kabupaten Bone, Sulawesi Selatan, seperti di bawah ini:
Data Responden:

\begin{tabular}{|c|c|c|}
\hline \multicolumn{2}{|c|}{$\begin{array}{l}\text { I. DATA MASYARAKAT (RESPONDEN) } \\
\text { (Tanda bold adalah jawaban masyarakat/responden) }\end{array}$} & \multirow[t]{2}{*}{$\begin{array}{c}\text { Diisi } \\
\text { Oleh } \\
\text { Petugas }\end{array}$} \\
\hline $\begin{array}{l}\text { Nomer } \\
\text { Responden }\end{array}$ & & \\
\hline Umur & Tahun 27 & \\
\hline Jenis Kelamin & 1. Laki-laki & \\
\hline $\begin{array}{l}\text { Pendidikan } \\
\text { Terakhir }\end{array}$ & $\begin{array}{ll}\text { 1. } & \text { SD Kebawah } \\
\text { 2. } & \text { SLTP } \\
\text { 3. } & \text { SLTA } \\
\text { 4. } & \text { D1-D3 - D4 } \\
\text { 5. } & \text { S-1 } \\
\text { 6. } & \text { S-2 Ke Atas } \\
\end{array}$ & \\
\hline Pekerjaan Utama & $\begin{array}{ll}\text { 1. } & \text { PNS/ TNI/ Polri. } \\
\text { 2. } & \text { Pegawai Swasta. } \\
\text { 3. } & \text { Wiraswasta/ Usahawan } \\
\text { 4. } & \text { Pelajar/Mahasiswa. } \\
\text { 5. } & \text { Lainnya. } \\
\end{array}$ & \\
\hline \multicolumn{3}{|l|}{ Nama } \\
\hline NIP/DATA LAIN & & \\
\hline
\end{tabular}

II. PENDAPAT RESPONDEN TENTANG PELAYANAN II. PENDAPAT RESPONDEN TENTANG PELAYANAN PUBLIK (Tanda bold adalah jawaban masyarakat/responden)

\begin{tabular}{|c|c|c|c|}
\hline 1. Bagaimana pemahaman Saudara & $P *)$ & 6. Bagaimana pendapat Saudara tentang & $P *)$ \\
\hline $\begin{array}{l}\text { tentang kemudahan prosedur } \\
\text { pelayanan di unit ini. } \\
\text { a. Tidak mudah. } \\
\text { b. Kurang mudah. } \\
\text { c. Mudah. } \\
\text { d. Sangat mudah. }\end{array}$ & $\begin{array}{l}1 \\
2 \\
3 \\
4\end{array}$ & $\begin{array}{l}\text { tanggung jawab petugas dalam memberikan } \\
\text { pelayanan. } \\
\text { a. Tidak bertanggung jawab. } \\
\text { b. Kurang bertanggung jawab. } \\
\text { c. Bertanggung jawab. } \\
\text { d. Sangat bertanggung jawab. }\end{array}$ & $\begin{array}{l}1 \\
2 \\
3 \\
4\end{array}$ \\
\hline $\begin{array}{l}\text { 2. Bagaimana pendapat Saudara } \\
\text { tentang kesesuaian persyaratan } \\
\text { pelayanan dengan jenis } \\
\text { pelayanannya. } \\
\text { a. Tidak sesuai. } \\
\text { b. Kurang Sesuai. } \\
\text { c. Sesuai. } \\
\text { d. Sangat sesuai. } \\
\end{array}$ & $\begin{array}{l}1 \\
2 \\
3 \\
4\end{array}$ & $\begin{array}{l}\text { 7. Bagaimana pendapat Saudara tentang } \\
\text { kemampuan petugas dalam memberikan } \\
\text { pelayanan. } \\
\text { a. Tidak mampu. } \\
\text { b. Kurang mampu. } \\
\text { c. Mampu. } \\
\text { d. Sangat mampu. }\end{array}$ & $\begin{array}{l}1 \\
2 \\
3 \\
4\end{array}$ \\
\hline $\begin{array}{l}\text { 3. Bagaimana pendapat Saudara } \\
\text { tentang kedisiplinan petugas } \\
\text { dalam memberikan pelayanan. } \\
\text { a. Tidak disiplin. } \\
\text { b. Kurang disiplin. } \\
\text { c. Disiplin. } \\
\text { d. Sangat disiplin. }\end{array}$ & $\begin{array}{l}1 \\
2 \\
3 \\
4\end{array}$ & $\begin{array}{l}\text { 8. Bagaimana pendapat Saudara tentang } \\
\text { kecepatan pelayanan di unit ini. } \\
\text { a. Tidak cepat. } \\
\text { b. Kurang cepat. } \\
\text { c. Cepat. } \\
\text { d. Sangat cepat. }\end{array}$ & $\begin{array}{l}1 \\
2 \\
3 \\
4\end{array}$ \\
\hline $\begin{array}{l}\text { 4. Bagaimana pendapat Saudara } \\
\text { tentang kesopanan dan }\end{array}$ & $\left(P^{*}\right)$ & $\begin{array}{l}\text { 9. Bagaimana pendapat Saudara tentang } \\
\text { ketepatan pelaksanaan terhadap jadwal } \\
\text { waktu pelayanan. }\end{array}$ & $\left.\mathrm{P}^{*}\right)$ \\
\hline $\begin{array}{l}\text { keramahan petugas dalam } \\
\text { memberikan pelayanan. } \\
\text { a. Tidak sopan dan ramah } \\
\text { b. Kurang sopan dan ramah. } \\
\text { c. Sopan dan ramah. } \\
\text { d. Sangat sopan dan ramah. } \\
\end{array}$ & $\begin{array}{l}1 \\
2 \\
3 \\
4\end{array}$ & $\begin{array}{l}\text { a. Selalu tidak cepat. } \\
\text { b. Kadang-kadang cepat. } \\
\text { c. Banyak tepatnya. } \\
\text { d. Selalu cepat. }\end{array}$ & $\begin{array}{l}1 \\
2 \\
3 \\
4\end{array}$ \\
\hline $\begin{array}{l}\text { 5. Bagaimana pendapat Saudara } \\
\text { tentang kesesuaian antara biaya } \\
\text { yang dibayarkan dengan biaya } \\
\text { yang telah ditetapkan. } \\
\text { a. Selalu tidak sesuai. } \\
\text { b. Kadang-kadang sesuai. } \\
\text { c. Banyak sesuainya. } \\
\text { d. Selalu sesuai. } \\
\text {. }\end{array}$ & $\begin{array}{l}1 \\
2 \\
3 \\
4\end{array}$ & $\begin{array}{l}\text { 10. Bagaimana pendapat Saudara tentang } \\
\text { kenyamanan di lingkungan unit } \\
\text { pelayanan. } \\
\text { a. Tidak nyaman. } \\
\text { b. Kurang nyaman. } \\
\text { c. Nyaman. } \\
\text { d. Sangat nyaman. }\end{array}$ & $\begin{array}{l}1 \\
2 \\
3 \\
4\end{array}$ \\
\hline
\end{tabular}


Hasil jawaban 10 orang responden terhadap pelayanan publik Pemerintah Daerah Kabupaten Bone, sebagaimana tersebut di bawah ini:

\begin{tabular}{||l|l|l|l|l|l||l|l|l||l|l|l||}
\hline \hline $\begin{array}{l}\text { Res } \\
\text { pon } \\
\text { den }\end{array}$ & $\begin{array}{l}\text { Pendi } \\
\text { dikan }\end{array}$ & $\begin{array}{c}\text { Perta- } \\
\text { nyaan } \\
\mathbf{1}\end{array}$ & $\begin{array}{c}\text { Perta- } \\
\text { nyaan } \\
\mathbf{2}\end{array}$ & $\begin{array}{l}\text { Perta- } \\
\text { nyaan } \\
\mathbf{3}\end{array}$ & $\begin{array}{c}\text { Perta- } \\
\text { nyaan } \\
\mathbf{4}\end{array}$ & $\begin{array}{l}\text { Perta- } \\
\text { nyaan } \\
\mathbf{5}\end{array}$ & $\begin{array}{c}\text { Perta- } \\
\text { nyaan } \\
\mathbf{6}\end{array}$ & $\begin{array}{l}\text { Perta- } \\
\text { nyaan } \\
\mathbf{7}\end{array}$ & $\begin{array}{l}\text { Perta- } \\
\text { nyaan } \\
\mathbf{8}\end{array}$ & $\begin{array}{l}\text { Perta- } \\
\text { nyaan } \\
\mathbf{9}\end{array}$ & $\begin{array}{l}\text { Perta- } \\
\text { nyaan } \\
\mathbf{1 0}\end{array}$ \\
\hline 1. & $\begin{array}{l}\text { SLT } \\
\text { A }\end{array}$ & c & c & c & d & c & c & c & d & c & d \\
\hline 2. & S1 & d & c & c & d & c & d & c & d & c & d \\
\hline 3. & $\begin{array}{l}\text { SLT } \\
\text { A }\end{array}$ & d & c & c & c & d & c & c & c & d & c \\
\hline 4. & $\begin{array}{l}\text { SLT } \\
\text { A }\end{array}$ & c & c & d & c & d & c & c & c & d & d \\
\hline 5. & S1 & c & d & d & c & c & d & c & d & c & d \\
\hline 6. & S1 & d & d & c & c & d & c & c & c & c & d \\
\hline 7. & SLTP & c & d & d & c & c & c & d & c & d & d \\
\hline 9. & SLTP & d & c & c & d & c & c & c & c & d & d \\
\hline 10. & $\begin{array}{l}\text { SLT } \\
\text { A }\end{array}$ & d & c & d & d & c & d & c & c & c & d \\
\hline
\end{tabular}

Dari hasil jawaban responden terhadap kepuasan pelayanan publik Pemerintah Daerah Kabupaten Bone, maka dapat dianalisis:

1. Pertanyaan nomor 1 responden yang menjawab c (mudah) sebanyak 4 dan d (sangat mudah) sebanyak 6. Nilai c sama dengan 3 , jadi $3 \times 4=12$. Nilai d sama dengan 4 , jadi 4 × $6=24$. Hal ini menunjukkan, bahwa kemudahan prosedur pelayanan pelayanan publik pemerintah daerah Kabupaten Bone sangat mudah.

2. Pertanyaan nomor 2 responden yang menjawab c (sesuai) sebanyak 6 dan d (sangat sesuai) sebanyak 4. Nilai c sama sengan 3 , jadi $3 \times 6=18$. Nilai d sama sengan 4 , jadi $4 \times 4=16$. Hal ini menunjukkan, bahwa kesesuaian persyaratan pelayanan dengan jenis pelayanannya pelayanan publik pemerintah daerah Kabupaten Bone sesuai.

3. Pertanyaan nomor 3 responden yang menjawab c (disiplin) sebanyak 4 dan d (sangat disiplin) sebanyak 6. Nilai c sama sengan 3 , jadi $3 \times 4=12$. Nilai d sama sengan 4 , jadi $4 \times 6=24$. Hal ini menunjukkan, bahwa kedisiplinan petugas dalam memberikan pelayanan publik pemerintah daerah Kabupaten Bone sangat disiplin.

4. Pertanyaan nomor 4 responden yang menjawab c (sopan dan ramah) sebanyak 6 dan d (sangat sopan dan ramah) sebanyak 4. Nilai c sama sengan 3 , jadi $3 \times 6=18$. Nilai d sama sengan 4 , jadi $4 \times 4=16$. Hal ini menunjukkan, bahwa kesopanan dan keramahan petugas dalam memberikan memberikan pelayanan publik pemerintah daerah Kabupaten Bone sopan dan ramah.

5. Pertanyaan nomor 5 responden yang menjawab c (banyak sesuainya) sebanyak 5 dan d (selalu sesuai) sebanyak 5 . Nilai c sama sengan 3 , jadi $3 \times 5=15$. Nilai d sama sengan 4 , jadi $4 \times 5=20$. Hal ini menunjukkan, bahwa kesesuaian antara biaya yang dibayarkan dengan biaya yang telah ditetapkan memberikan pelayanan publik pemerintah daerah Kabupaten Bone selalu sesuai.

6. Pertanyaan nomor 6 responden yang menjawab c (bertanggung jawab) sebanyak 6 dan d (sangat bertanggung jawab) sebanyak 4. Nilai c sama sengan 3 , jadi $3 \times 6=18$. Nilai d sama sengan 4 , jadi $4 \times 4=16$. Hal ini menunjukkan, bahwa tanggung jawab petugas dalam memberikan pelayanan publik pemerintah daerah Kabupaten Bone bertanggung jawab.

7. Pertanyaan nomor 7 responden yang menjawab c (mampu) sebanyak 7 dan d (sangat mampu) sebanyak 3. Nilai c sama sengan 3 , jadi $3 \times 7=21$. Nilai d sama sengan 4 , jadi 4 × $3=12$. Hal ini menunjukkan, bahwa kemampuan petugas dalam memberikan pelayanan publik pemerintah daerah Kabupaten Bone mampu.

8. Pertanyaan nomor 8 responden yang menjawab c (cepat) sebanyak 7 dan d (sangat cepat) sebanyak 3 . Nilai c sama sengan 3 , jadi $3 \times 7=21$. Nilai d sama sengan 4 , jadi $4 \times 3=12$. Hal ini menunjukkan, bahwa kecepatan dalam memberikan pelayanan publik pemerintah daerah Kabupaten Bone cepat. 
9. Pertanyaan nomor 9 responden yang menjawab c (banyak tepatnya) sebanyak 6 dan d (selalu tepat) sebanyak 3. Nilai c sama sengan 3 , jadi $3 \times 6=18$. Nilai d sama sengan 4 , jadi $4 \times 4=16$. Hal ini menunjukkan, bahwa ketepatan pelaksanaan terhadap jadwal waktu dalam memberikan pelayanan publik pemerintah daerah Kabupaten Bone banyak tepatnya.

10. Pertanyaan nomor 10 responden yang menjawab c (nyaman) sebanyak 3 dan d (sangat nyaman) sebanyak 7 . Nilai c sama sengan 3 , jadi $3 \times 3=9$. Nilai d sama sengan 4 , jadi $4 \times 7=21$. Hal ini menunjukkan, bahwa kenyamanan di lingkungan unit pelayanan publik pemerintah daerah Kabupaten Bone sangat nyaman.

\section{PENUTUP}

Berdasarkan permasalahan yang diajukan dan pembahasan pada bab-bab sebelumnya dapat disimpulkan, bahwa Pemerintah Daerah Kabupaten Bone telah menerapkan dan mengimplementasi standar pelayanan publik yang baik. Pelayanan publik, antara lain dengan menetapkan:

1. Standar Pelayanan;

2. Maklumat Pelayanan;

3. Sistem Informasi Pelayanan Publik;

4. Pengelolaan Sarana, Prasarana, dan/ atau Fasilitas Pelayanan Publik Pengawasan internal;

5. Pelayanan Khusus;

6. Biaya/Tarif Pelayanan Publik;

7. Perilaku Pelaksana dalam Pelayanan;

8. Pengawasan Penyelenggaraan Pelayanan Publik;

9. Pengelolaan Pengaduan;

10. Penilaian Kinerja;

11. Peran serta Masyarakat.

Hasil penilaian pelayanan publik Pemerintah Daerah Kabupaten Bone menunjukkan bobot penilaian pada Form
A memperoleh nilai 93. Hal ini membuktikan penilaian pelayanan publik yang diselenggarakan oleh Pemerintah Daerah Kabupaten Bone sangat baik.

Selanjutnya dari hasil jawaban responden terhadap pelayanan publik Pemerintah Daerah Kabupaten Bone dapat disimpulkan, bahwa pelayanan publik Pemerintah Daerah Kabupaten Bone adalah:

1. Sangat mudah;

2. Sesuai prosedur;

3. Petugasnya sangat disiplin;

4. Petugasnya sopan dan ramah;

5. Kesesuaian biaya selalu sesuai;

6. Petugasnya bertanggung jawab;

7. Petugasnya mampu;

8. Pelayanannya cepat;

9. Pelayanannya banyak tepatnya;

10. Lingkungannya sangat nyaman.

Kegiatan Kementerian Negara Pendayagunaan Aparatur Negara dan Reformasi Birokrasi dalam menyelenggarakan penilaian pelayanan publik merupakan kegiatan yang diharapkan dapat menunjukkan peningkatan kinerja dan menumbuhkan budaya pelayanan pubilik yang lebih baik, pada Unit Pelayanan Publik yang berada di lingkungan Kementerian, Lembaga Pemerintah non Kementerian, Kepolisian Negara RI, Kejaksaan Agung RI, Badan Usaha Milik Negara dan Pemerintah Daerah. Karena dengan adanya kegiatan ini, maka masingmasing unit pelayanan yang akan dinilai dan berlomba untuk mencapai hasil yang optimal. Semangat untuk dapat memberikan pelayanan yang optimal dari masingmasing unit tersebut nantinya akan menjadi suatu budaya pelayanan yang prima. 


\section{DAFTAR PUSTAKA}

A. Buku

Anderson, James E. Public Policy: Making, USA: Holt, Renehart and Winston, 1979

Anggara, Sahya. Perbandingan Administrasi Negara, Bandung: CV. Pustaka Setia, 2012

Anggriani, Jum. Hukum Administrasi Negara, Yogyakarta: Graha Ilmu, 2012

Ashshofa, Burhan. Metode Penelitian Hukum, Jakarta: Rineka Cipta, 2010

Asshiddiqie, Jimly. Gagasan Kedaulatan Rakyat dalam Konstitusi dan Pelaksanaannya di Indonesia, Jakarta: PT. Ichtiar Baru Van Hoeve, 1994

Hukum Tata Negara dan Pilar-pilar Demokrasi, Cet. Ke 2, Jakarta: Sinar Grafika, 2012

Pengantar Hukum Tata Negara, Cet. Ke 5, Jakarta: PT. Raja Grafindo Persada, 2013.

Pokok-pokok Hukum Tata Negara Indonesia Pasca Reformasi, Jakarta: PT. Bhuana Ilmu Populer, 2007

Atmosudirdjo, Prajudi, Hukum Administrasi Negara, Cetakan Keenam, Jakarta: Ghalia Indonesia, 1983

Budiardjo, Miriam, Dasar-Dasar Ilmu Politik, Jakarta: Gramedia, 1980
Bungin, H.M. Burhan, Penelitian Kualitatif : Komunikasi, Ekonomi, Kebijakan Publik, dan Ilmu Sosial Lainnya, Edisi Kedua, Cet. Ke 5, Jakarta: Kencana Prenada Media Group, 2011

Dune, William N. Pengantar Analisis Kebijakan Publik, edisi kedua, cet. Kelima, Yogyakarta: Gadjah Mada University Press, 2003

Dwiyanto, Agus. Mewujudkan Good Governance Melalui Pelayanan Publik, cet. Ketiga, Yogyakarta: Gadjah Mada University Press, 2008

Dwiyanto, Agus. Manajemen Pelayanan Publik : Peduli, Inklusif, dan Kolaboratif, cet. Kedua Edisi ke-2, Yogyakarta: Gadjah Mada University Press, 2011

Edwards III, George C. Implementing Public Policy, Washington D.C.: Congressional Quarterly Inc., 1980

Hardiyansyah, Kualitas Pelayanan Publik (Konsep, Dimensi, Indikator dan Implementasinya), Cetakan Pertama, Yogyakarta: Gaya Media, 2011

Indiahono, Dwiyanto. Kebijakan Publik Berbasis Dynamic Policy Analysis, Yogyakarta: Gava Media, 2009

Jauhari, Heri. Panduan Penulisan Skripsi : Teori dan Aplikasi, Bandung: CV. Pustaka Setia, 2010

Keban, Yeremias T. Enam Dimensi Strategis Administrasi Publik (Konsep, Teori dan Isu), Edisi Kedua, Yogyakarta: Penerbit Gava Media 
Kementerian Negara Pendayagunaan Aparatur Negara \& Reformasi Birokrasi dan Lembaga Administrasi Negara, Peningkatan Kualitas Pelayanan Publik dengan Partisipasi Masyarakat "Metode Praktis, Cepat dan Murah untuk Meningkatkan Kualitas Pelayanan di Unit Pelayanan Publik"

Kusnadi, Moh. Dan Saragih, Bintan R. Ilmu Negara, Edisi Revisi, Cet. Ke 4, Jakarta: Gaya Media Pratama, 2000

Kusnadi, Muh. \& Bintan R. Saragih, Ilmu Negara, Cetakan Kedua, Jakarta: Gaya Media Pratama, 1988.

Lotulung, Paulus Effendie. Et al., Hukum Administrasi Negara dan Good Governance, Jakarta: Penerbit Universitas Trisakti, 2010

M. Hadjon, Philipus. Beberapa Sistem Tentang Kontrol Segi Hukum Terhadap Pemerintah, Cetakan Pertama, Jakarta: PT Bhuana Ilmu Populer, 1986

M. Hadjon, Philipus. Cs, Pengantar Hukum Administrasi Negara (Introduction to the Indonesian Administrasi Law), Cetakan Ketiga, Yogyakarta: Gadjah Mada University Press, 1994

Mahfud M.D, Muh. Dasar dan Struktur Ketatanegaraan Indonesia, Edisi Revisi, Jakarta: Rineka Cipta, 2001

Mazmanian, Daniel A. and Paul A. Sabatier George C. Edwards III, Implementation and Public Policy, USA: Scott and Foresman Company, 1983
Moore, Mark H. Creating Public Value, second printing, USA: The President and Fellows of Harvard College, 1996

Munadi, Muhammad dan Barnawi, Kebijakan Publik di Bidang Pendidikan, Jakarta: Ar-Ruzz Media, 2011

Napitupulu, Paimin. Pelayanan Publik dan Customer Satifaction : Prinsipprinsip Dasar agar Pelayanan Publik Lebih Berorientasi pada Kepuasan dan Kepentingan Masyarakat, Bandung: PT. Alumni, 2007

Nurwandi, Achmad. Manajemen Pelayanan Publik: Lampiran UU Nomor 25 Tahun 2009, tentang Pelayanan Publik, Yogyakarta: PT. Sinergi Visi Utama, 2010

Pramusinto, Agus dan Erwan Agus Purwanto, Reformasi Kepemimpinan dan Pelayanan Publik: Kajian tentang Pelaksanaan Otonomi Daerah di Indonesia, Yogyakarta: Gava Media, 2009

Purbopranoto, Kuntjoro. Perkembangan Hukum Administrasi Indonesia, Cetakan Pertama, Bandung: Angkasa Offset 1981

Ranadiresa, Hendarmin. Visi Politik Amandemen UUD 45 Menuju Konstitusi yang Berkedaulatan Rakyat, Jakarta: Penerbit Yayasan Pancur Sawah, 2002.

Reformasi Birokrasi dalam Pelayanan Publik, Jakarta: CV. Eko Jaya, 2009 
Ridwan, Juniarso dan Achmad Sodik Sudrajat, Hukum Administrasi Negara dan Kebijakan Pelayanan Publik, Cetakan ke 1, Bandung: Penerbit Nuansa, 2010

Seri Tata Kelola Perusahaan Jilid II, Peranan Dewan Komisaris dan Komite Audt dalam Pelaksanaan Corporate Governance (Tata Kelola Perusahaan), Jakarta: Forum for Corporate Governance in Indonesia.

Seri Tata Kelola Perusahaan, Corporate Governance Tata Kelola Perusahaan, Jakarta: Forum for Corporate Governance in Indonesia.

Shafritz, Jay M. and Albert C. Hyde, Classic of Public Administration, South Lincoln: Harcourt Brace \& Company, 1997

Sinambela, Lilian Poltak. dkk, Reformasi Pelayanan Publik: Teori Kebijakan dan Implementasi, cet. Keenam, Jakarta: PT. Bumi Aksara, 2011

Siswadi, Edi. Birokrasi Masa Depan Menuju Tata Kelola Pemerintahan yang Efektif dan Prima, Bandung: Mutiara Press, 2012

Soekanto, Soerjono. Pengantar Penelitian Hukum, Cetakan Ketiga, Jakarta: UIPRESS, 1986

Soekarwo dkk, Pelayanan Publik dari Dominasi ke Partisipasi, Surabaya: Airlangga University Press, 2006.

Soeprapto, Maria Farida Indrati. Ilmu Perundang-undangan Dasar-Dasar dan Pembentukannya, Yogyakarta: Kanisius, 1998
Soeprapto, Maria Farida Indrati. Ilmu Perundang-undangan Dasar-Dasar dan Pembentukannya, Yogyakarta: Kanisius, 1998

Sulistiyani, Ambar Teguh. Memahami Good Governance dalam Perspektif Sumber Daya Manusia, Yogyakarta: Gava Media, 2004

Sumardjono, Maria S.W. Pedoman Pembuatan Usulan Penelitian : Sebuah Panduan Dasar, Jakarta: PT. Gramedia Pustaka Utama, 1996

Surjadi, Pengembangan Kinerja Pelayanan Publik, Bandung: PT. Refika Aditama, 2009

Sutedi, Adrian. Good Corporate Governance, Jakarta: Sinar Grafika, 2011

Syafri, Wirman. Studi tentang Administrasi Publik, Jakarta: Erlangga.

Tangkilisan, Hessel Nogi S. Kebijakan Publik Untuk Pemimpin Berwawasan Internasional, Yogyakarta: Penerbit Balairung \& Co, 2003

Tanya, Bernard L. dkk, Teori Hukum Strategi Tertib Manusia Lintas Ruang dan Generasi, cet. III, Yogyakarta: Genta Publishing, 2010

Tjandra, W. Riawan. Hukum Administrasi Negara, Yogyakarta: Penerbit Universitas Atma Jaya, 2012.

Utomo, Warsito. Dinamika Administrasi Publik (Analisis Seputar Isu-isu Kontemporer dalam Administrasi Publik), Cet. Kedua, Yogyakarta: Pustaka Pelajar, 2007 
Wahab, Solichin Abdul. Analisis Kebijaksanaan dari Formulasi ke Implementasi Kebijaksanaan Negara, Edisi Kedua Cet. Ke-6, Jakarta: PT. Bumi Aksara, 2008

Pengantar Analisis Kebijakan Publik, Malang: Universitas Muhammadiyah Malang Press, 2008

Widi, Restu Kartiko. Asas Metode Penelitian : Sebuah Pengenalan dan Penuntun Langkah Dem Langkah Pelaksanaan Penelitian, Yogyakarta: Graha Ilmu, 2010

Widodo, Joko. Analisis Kebijakan Konsep dan Aplikasi Analisis Proses Kebijakan Publik, Cet. Kedua, Malang: Bayumedia Publishing, 2008

Wiratno, Pengantar Hukum Administrasi Negara, Cetakan Keempat, Jakarta: Penerbit Universitas Trisakti, 2016

Zarkasyi, Moh. Wahyudin. Good Corporate Governance pada Badan Usaha Manufaktur, Perbankan, dan Jasa Keuangan Lainnya, Bandung: Alfabeta, 2008

B. Peraturan Perundang-Undangan

Undang-Undang Dasar RI 1945, Amandemen Pertama, Ke Dua, Ke Tiga dan Ke Empat, Citra Umbara, Bandung, 2002

Undang-Undang Nomor RI 5 Tahun 1986, tentang Peradilan Tata Usaha Negara, internet, http:www.legalitas.org. Undang-
Undang Nomor RI 14 Tahun 2008, tentang Keterbukaan Informasi Publik, internet, http:www.legalitas.org.

Undang-Undang Nomor RI 37 Tahun 2008, tentang Ombudsman, internet, http:www.legalitas.org.

Undang-Undang Nomor RI 25 Tahun 2009, tentang Pelayanan Publik, internet, http:www.legalitas.org.

C. Makalah

Peningkatan Kualitas Pelayanan Publik dengan Partisipasi Masyarakat "Metode Praktis, Cepat dan Murah untuk Meningkatkan Kualitas Pelayanan di Unit Pelayanan Publik, kerjasama Kementerian Negara Pendayagunaan Aparatur Negara RI, Lembaga Administrasi Negara RI dan Deutsche Gesellshaft fur Technische Zusammenarbeit (GTZ) GmbH. Raksaka Mahi, Birokrasi dan Daya Saing Nasional, Makalah Seminar Reformasi Birokrasi, Kementerian Negara Perencanaan Pembangunan Nasional/Badan Perencanaan Pembangunan Nasional, Jakarta, 2 Juni 2008

Sofian Effendi, Agenda Reformasi Birokrasi Pemerintahan yang Responsif, Efisien dan Efektif, Makalah Seminar Reformasi Birokrasi, Kementerian Negara Perencanaan Pembangunan Nasional/Badan Perencanaan Pembangunan Nasional, Jakarta, 2 Juni 2008 